\title{
Dividend persistence and earnings management in emerging
} markets*

\author{
Orleans Silva Martins ${ }^{1}$ \\ (D) https://orcid.org/0000-0002-4966-0347 \\ Email: orleansmartins@ccsa.ufpb.br \\ Raíssa Aglé Moura de Sousa² \\ (D) https://orcid.org/0000-0001-9302-5087 \\ Email: raissa.agle@ufba.br \\ Luiz Felipe de Araújo Pontes Girão ${ }^{3}$ \\ (D) https://orcid.org/0000-0002-3639-7340 \\ Email: felipe.pontes@tc.com.br
}

\author{
${ }^{1}$ Universidade Federal da Paraíba, Centro de Ciências Sociais Aplicadas, Departamento de Finanças e Contabilidade, João Pessoa, PB, Brazil \\ ${ }^{2}$ Universidade Federal da Bahia, Faculdade de Ciências Contábeis, Salvador, BA, Brazil \\ ${ }^{3}$ TC TradersClub S.A., Diretoria Educacional e de Pesquisa \& Desenvolvimento, São Paulo, SP, Brazil
}

Received on 08.28.2020 - Desk acceptance on 09.21.2020 - 4th version approved on 05.27.2021 - Ahead of print on 10.25.2021

Editor-in-Chief: Fábio Frezatti

Associate Editor: Fernanda Finotti Cordeiro

\begin{abstract}
We investigate the relationship between dividend persistence and earnings management, considering the levels of economic performance and risk in emerging countries. Earnings are important for valuation models and dividends have evidence that suggests greater persistence, however, there is no evidence on the effect of earnings management on dividend persistence in emerging countries. Despite the substantial growth of emerging markets in the last decades, the degree of informational efficiency and the legal protection for investors is inferior to developed countries, and this is a potential risk for investors who prefer to receive dividends as a way of avoiding expropriation by managers who can manage the firms' earnings. We show that the reduction in macroeconomic volatility and the uncertainties concerning a country's performance and risk improve dividend persistence. Thus, even in the face of earnings manipulations, dividends are better inputs for valuation models. Using the persistence models of Dechow and Schrand (2004) and Lintner (1956), we interact the dividend persistence with firms' earnings management and some indicators of a country's economic performance and risk for 7,536 publicly traded firms from 20 countries, included in the Morgan Stanley Capital International (MSCI) Emerging Markets Index from 2000 to 2016. We find that in emerging countries dividends are more persistent than earnings. If a company pays United States dollars (USD) 1.00 in dividends, then, on average, US\$ 0.89 will persist into next year's dividends (for earnings, only US\$ 0.76 persists). We find that, in addition to the past dividends and current earnings presented by Lintner (1956), current dividends are a function of earnings management volume because this event reduces dividend persistence.
\end{abstract}

Keywords: earnings persistence, dividend payout, discretionary accruals.

Correspondence address

Orleans Silva Martins

Universidade Federal da Paraíba, Centro de Ciências Sociais Aplicadas, Departamento de Finanças e Contabilidade

Via Expressa Padre Zé, 289 - CEP 58051-900

Castelo Branco III - João Pessoa - PB - Brazil

*Work received an honorable mention in the Prêmio CFA Society Brazil de Inovação Financeira, São Paulo, SP, Brazil, August 2019. 


\section{INTRODUCTION}

The discussion about dividends began with the dividend relevance theory (Gordon, 1963; Lintner, 1956), which broadly states that the distribution of earnings is a factor of relevance in the company's valuation. The assumed view is that decisions to retain corporate earnings, rather than distribute them, would be riskier for the investor, who does not know whether these retained earnings will be applied to good projects that will generate future capital gains. In emerging markets, the degree of informational efficiency and legal protection for investors is inferior to developed countries (La Porta et al., 1997, 2000), and less attention is devoted to examining their information environment, despite the substantial growth of emerging markets (Ghysels et al., 2016).

In this sense, the objective of this study is to investigate the relationship between dividend persistence and earnings management of firms, especially concerning the different levels of economic performance and risk in emerging countries. For this, we use the argument of the bird-inhand theory, which assumes that investors believe that it is better to have a bird in hand now, which would be the dividends received, than capital gains in the future, which represents the uncertainty of a possible increase in their equity in the future (Gordon, 1963; Lintner, 1956). Moreover, this theory also supports the argument that investors prefer receiving dividends instead of giving up your payment in current periods in exchange for future returns.

This argument is contrary to the dividend irrelevance theory (Miller \& Modigliani, 1961), which supports that investors do not mind giving up dividends in the current period for future capital gains since the valuation of a firm's stock in the future would compensate for the abdication of receiving dividends in the current period. Our argument is contrary, first, because the irrelevance of Miller and Modigliani (1961) requires the assumptions of no brokerage fees, transaction costs, and taxes, even no tax differences between distributed and undistributed earnings, or between dividends and capital gains. Second, because the country's risk characteristics, such as economic recession and sovereign risk, may influence shareholders' preference for current dividends or future capital gains (Dimitras et al., 2015; Oshiro \& Saruwatari, 2005). In practice, these elements make a difference.

In this sense, raising the dividend payments without ensuring that profits will increase continuously can be unwise, since there is a possibility that dividends would be reduced in the future, whether due to a financial crisis or the high risk of a country, which can provoke discontent among investors (Marsh \& Merton, 1987). However, to keep shareholders satisfied, managers can preserve certain levels of dividend payments constantly, which makes the distribution of dividends persistent over the periods, since reducing such dividends would not be an acceptable decision to the shareholders (Chan et al., 2018).

We can conceptualize dividend persistence as the dividend's sustainability over time, which is also important for the valuation models based on a dividend discount. This is in line with the literature on earnings persistence, which points out that "persistence" is a concept that refers to the earning's sustainability over time (Dechow \& Schrand, 2004) and that persistent earnings are better inputs to the equity valuation models (Dechow et al., 2010).

In this context, if persistent earnings are important for valuation models (Dechow et al., 2010), and dividends must be more persistent than earnings because managers tend to preserve constant dividend payments to satisfy shareholders (Chan et al., 2018), our motivation is to comparatively examine the dividend persistence in emerging countries where investors can find economic recessions, a higher sovereign risk, and less legal protection than in developed countries. Thus, since it is evident in the literature the importance of more persistent inputs (either earnings or dividends) for valuation models (Dechow et al., 2010; Damodaran, 2012), we clarify that in this study we analyzed the element of persistence, and not its effect on valuation models.

Within this context, earnings can be managed to obtain more persistent dividends. According to Dechow et al. (2010), earnings management occurs when managers exercise judgment about a firm's financial information and operating activities to change its accounting information to suit the managers' interests. Besides, one interest of managers may be the influence on the firm's equity valuation, since earnings can be managed to achieve a higher level of shareholder satisfaction, which prolongs their stay at the company (Chan et al., 2018).

However, in return for this satisfaction, managers may be destroying value in the firm by generating private benefits, especially when they are also shareholders of the firm because they have greater incentives to manage earnings and maintain the dividend persistence. Over time, paying constant dividend levels may prevent the firm from investing in new projects and may stop adding 
value to the business. In this context, the objective of this study is to investigate the relationship between dividend persistence and the earnings management of the companies in emerging markets, considering the countries' economic performance and risk.

From the economic and investor protection aspects, La Porta et al. (1997) emphasize that emerging countries do not have the level of informational efficiency and legal protection of developed countries, and, because of this, emerging markets have a more fragile information environment. Nevertheless, La Porta et al. (2000) observe that firms use dividends to secure their reputation and moderate shareholder wealth, under the assumption that dividend payments are substitutes for good reputation, representing good protection for shareholders.

This tends to be more pronounced in countries with worse economic performance, financial crises, or higher risks (Dimitras et al., 2015; Marsh \& Merton, 1987). Also, Al-Najjar (2009) states that corporate dividend behavior in emerging countries reveals that there are target dividend payment ratios, unlike developed countries, and that prices tend to adjust to these target ratios, which increases the dividend persistence in emerging countries. Despite this isolated evidence and the visible relevance of studying the association between dividend persistence and earnings management in emerging countries, as far as we know, this is the first study to investigate these phenomena together, which increases their relevance and originality.

For this reason, we study a sample of 7,536 firms from 20 emerging countries included in the Morgan Stanley Capital International (MSCI) Emerging Markets
Index between 2000 and 2016. We can observe that, in general, the dividend payout ratio depends on the firm and country characteristics. Still, dividends are more persistent than earnings. Moreover, this finding can be drawn from the entire sample for most of the countries analyzed individually (14 out of 20). Considering Lintner's (1956) model, it is possible to verify that dividends are also persistent with the negative influence of earnings management. Finally, a country's gross domestic product (GDP) growth positively affects the dividend persistence and improving the sovereign risk level (SRI) of the country increases the predictability of corporate dividends.

We contribute to the literature by demonstrating that firms in emerging countries tend to manage their earnings to meet market expectations, especially concerning the firm's performance, which has a negative effect on dividend persistence. In addition to the past dividends and current earnings pointed out by Lintner (1956), we found that current dividends are a function of earnings management. Dividends have their persistence reduced by earnings management, but it remains less volatile than corporate earnings, which qualifies dividends as a better input for the valuation models. This is especially true because of the reduction of macroeconomic volatility and uncertainties about a country's performance and risk improve the predictability of corporate performance and increase the persistence of dividends over time.

In addition to this introduction, this study presents the development of the hypotheses in section 2 , the method in section 3 , the results in section 4 , and the conclusion in section 5 .

\section{HYPOTHESES DEVELOPMENT}

The literature on earnings persistence relates that earnings are more persistent when they are sustainable over time (Dechow et al., 2010; Dechow \& Schrand, 2004). According to Dechow and Schrand (2004), it is possible to predict future earnings through past earnings, and if these forecasts are minimally disrupted by the expected values, it can be considered that the accounting information has a better quality. Thus, more persistent earnings are better inputs to equity valuation models, consistent with Graham and Dodd's view, in which earnings are a summary metric of expected cash flows (Dechow et al., 2010). Also, by considering earnings persistence as an important quality of accounting information, Dechow et al. (2010) observe that this quality can be positively associated with investment efficiency.
Dividend persistence can be understood as the sustainability of the dividend over time. In this sense, Lintner (1956) observes that dividends are not adjusted for temporary earnings, with a greater tendency to remain constant over time, that is, to be more persistent than earnings, although temporary changes in earnings may lead to volatility in dividends. Besides, Chan et al. (2018) argue that dividends are more smoothed than earnings and, therefore, tend to be more persistent, because firms are likely to maintain their dividend volumes and only increase the volume of profit distribution if earnings show significant increases, which make earnings more volatile than dividends. Consequently, firms make partial adjustments to dividend payments because of recent changes in earnings. The idea is that a greater change in 
dividends, to the previous change in earnings, would be a clear signal that managers tend to preserve constant dividend payments to satisfy shareholders (Chan et al., 2018).

In this context, we can see that earnings and dividends may be important keys for investors to decide whether or not to invest in a firm (Dechow et al., 2010), with the expectation that dividends are more persistent than earnings (Chan et al., 2018). Based on these arguments, we present the first hypothesis of this study:

$\mathrm{H}_{1}$ : In emerging markets, the dividends are more persistent than the earnings.

Parallel to earnings persistence, we must also consider earnings volatility. When earnings are volatile, the forecast of a firm's future cash flows is compromised, since earnings volatility is inversely related to earnings persistence (Dichev \& Tang, 2009). These authors also claim that earnings volatility may be tied to earnings management as firms smooth their earnings so that a firm's performance is more predictable.

Earnings can also be managed to make dividends more persistent. The persistence of dividends promotes the company a better reputation and moderates the shareholders' wealth, especially when we assume that dividend payments are substitutes for a good reputation. These payments replace good protection, especially in emerging markets, because they have lower degrees of informational efficiency and legal protection for investors (La Porta et al., 1997, 2000). Besides, managers need to maintain access to capital markets, which justifies the reason why a firm seeks to preserve this reputation related to dividend payments (La Porta et al., 2000).

Discretionary management intervention may even condition dividend persistence, since earnings can be managed to a greater or lesser extent, because the managers consider that the market tends to reward a firm with better value due to the good reported results and being more predictable and for the managed earnings to exceed analysts' expectations (Damodaran, 2012). To manage earnings, for the firm or investment valuation, financial analysts generally perform reconciliations in the earnings reported by the firms being evaluated. The idea considered by analysts is that these earnings underwent a process of judgment, that is, of managers' choices, to thus not reveal the real economic and financial performance of the firm and, consequently, the real value-added or destroyed for shareholders by the firm (Damodaran, 2012).
The accruals' discretion in earnings can negatively influence a firm's earnings persistence and, consequently, the dividend persistence. For Daniel et al. (2008), managers treat the level of expected dividends as a threshold for earnings management. Thus, Rodrigues Sobrinho et al. (2014) found in Brazil that firms with a higher dividend payout also managed earnings at higher levels and that firms that pay dividends more frequently also showed more earnings management. In this sense, Srikanth and Durga Prasad (2015) assert that dividend-paying firms in India tend to maintain a constant record of the distribution of profits, and for this reason, they attempt to avoid large swings in these payments.

According to Daniel et al. (2008), firms' managers tend to manage their earnings upwards when they are below expected dividend levels. In contrast, it is possible to create a reserve of accruals when the earnings are above the expected dividend levels. Thus, we expect that:

$\mathrm{H}_{2}$ : In emerging markets, the dividend persistence is negatively associated with earnings management.

Dividend payments in any company are usually tied to the investment policy adopted by the firm. This fact is justified because the option to distribute profits or not and the increase or decrease of these distributions can imply a negative market reaction concerning the stock value (Lintner, 1956). Additionally, considering that current increases in profits cannot be followed by current increases in dividends, Chan et al. (2018) argue that, consistent with the concept of permanent profits introduced by Marsh and Merton (1987), if there is no tendency for permanent increases in profits, increases in dividend payments can be frequently suspended.

Since suspensions or reductions of dividend payments would cause dissatisfaction among investors, who do not respond favorably to the dividend cuts, such circumstances may lead to a firm's management smoothing dividends over the periods, which makes them more persistent (Chan et al., 2018). And the country's economic context also determines the persistence of earnings and dividends because earnings persistence and earnings response coefficients are positively associated with economic growth (Johnson, 1999).

In emerging markets, macroeconomic volatility is a more present phenomenon than in developed markets, which is reflected in the fluctuations and unpredictability in firms' performance variables (Malik \& Temple, 2009). This suggests that countries with more volatile economies 
and riskier contexts offer an environment less conducive to the persistence of earnings and dividends. In the Brazilian market, for example, in periods of global or local crises, models that are used to estimate earnings management and information persistence can present different behaviors (Silva et al., 2014). This is in line with the phenomena observed for European companies when a country's GDP is lower (Dimitras et al., 2015). In this sense, we present our third hypothesis:

$\mathrm{H}_{3}$ : In emerging markets, the dividend persistence is positively associated with GDP growth.

This context is consistent with Marsh and Merton (1987), who observe that a reduction of dividend payments can provoke discontent among investors, and with La Porta et al. (2000), who observe that firms use dividend payments to improve their reputation and to reduce investors' risk. This is especially true when a country has a more risky investment environment, as there is a greater propensity to manage its earnings to meet investors' expectations, which can affect earnings persistence and investors' preference for current dividends rather than future capital gains (Dimitras et al., 2015).

In this context, Oshiro and Saruwatari (2005) observe that SRI from credit rating agencies are good references for a country's risk because these agencies conduct exclusive interviews of both politicians and officers in the country and make macroeconomic forecasts based on confidential information. Therefore, as increased instability and risk in a country can negatively affect the performance of a company located in this country (Malik \& Temple, 2009), our last hypothesis predicts that:

$\mathrm{H}_{4}$ : In emerging markets, the dividend persistence is positively associated with a higher SRI score.

\section{METHOD}

Our sample comprises public firms that have stocks traded in the main stock exchanges of emerging countries included in the MSCI Emerging Markets Index. Firms without information on at least one analyzed variable in each year are excluded from the sample. Banks and financial institutions are also excluded because they have specificities in their capital structure that influence and mislead the analysis. Under these conditions, we analyze companies from 20 countries, namely, Brazil, Chile, China, Colombia, Czech Republic, Egypt, Greece, Hungary, India, Mexico, Peru, Poland, Qatar, Russia, Saudi Arabia, South Africa, South Korea, Taiwan, Turkey, and the United Arab Emirates.

The final sample consists of 7,536 nonfinancial firms from 2000 to 2016 with a total of 68,038 firm-years. We kept the firms that presented all the information necessary for the analysis in at least one year. It is important to emphasize that the main reason for the reduction of the initial sample is the variables about "dividends" since most firms do not disclose dividend information in the years analyzed, either because they do not pay dividends or because they have losses in most of the periods. All financial information is collected in United States dollars (USD) from Thomson Reuters Eikon (TRE).

\subsection{Estimation of Models and Earnings Management}

For the analyses of the relationships in this study, we used regression models by ordinary least squares (OLS) with year, industry, and country fixed-effects, with errors clustered at the firm level and with standard errors robust to heteroscedasticity and autocorrelation by Newey-West. We use this approach because there is a common concern about this empirical strategy, where the model errors can be correlated within each country, and they are possibly correlated within each industry (Dong \& Stettler, 2011). The error dependence may exist in the panel structure because errors are likely to be autocorrelated within firms, and macroeconomic shocks in our variables may produce cross-sectional error correlation (Petersen, 2009).

The presence of error correlation violates the standard assumptions of the OLS estimators. To address this issue, in our models, we include year, industry, and country fixed effects. These combined controls make possible the estimation of standard errors robust to the mentioned sources of error correlation and arbitrary forms of heteroscedasticity (Petersen, 2009). The use of this specification allows the isolation of common effects 
on the dependent variables of macroeconomic shocks during the analyzed period by controlling the effects of time-invariant industry and country characteristics. Finally, we have winsorized the variables at $1 \%$.

The first characteristic that relates to dividend persistence is a firm's earnings management. To estimate the earnings management, we use the Dechow et al. (2012) model, which adjusts the modified Jones model by including lagged accruals to capture their natural reversal in subsequent periods.

In equation 1 , for every firm $i$ in country $j$ and year $t$, the working capital accrual is calculated by $W C_{-} A C C_{\mathrm{ijt}}$ $=\left(\Delta C A_{\mathrm{ijt}}-\Delta C L_{\mathrm{ijt}}-\Delta C a s h_{\mathrm{ijt}}+\Delta S T D_{\mathrm{ijt}}\right) / A_{\mathrm{ijt}-1}$, where $\Delta C A_{\mathrm{ijt}}$ is the change in current assets from year $t-1$ to year $t$, $\Delta C L_{\mathrm{ijt}}$ is the change in current liabilities from year $t-1$ to year $t, \Delta \operatorname{Cash}_{\mathrm{ijt}}$ is the change in cash from year $t-1$ to year $t, \Delta S T D_{\mathrm{ijt}}$ is the change in short-term debt from year $t-1$ to year $t$, and $A_{\mathrm{itt}-1}$ is the total assets in year $t-1$. $\triangle R E V_{\mathrm{ijt}}$ is the change in revenues from year $t-1$ to year $t$ weighted by $A_{\mathrm{ijt}-1}, \Delta R E C_{\mathrm{ijt}}$ is the change in receivables from year $t-1$ to year $t$ weighted by $A_{\mathrm{ijt}-1}$, and $P P E_{\mathrm{ijt}}$ is the gross property, plant, and equipment weighted by $A_{\text {itt-1 }}$. Alternatively, a variable that indicates the number of years of mandatory International Financial Reporting Standards (IFRS) adoption is used (IFRSexp $p_{\mathrm{it}}$ ), because mandatory IFRS adoption has a restrictive effect on earnings management (Pelucio-Grecco et al., 2014), and IFRS experience can influence accounting information (Houqe $\&$ Monem, 2016). $\delta_{\mathrm{t}}, \gamma_{\mathrm{s}}$, and $\theta_{\mathrm{j}}$ are the fixed-effects, and $\varepsilon_{\mathrm{itt}}$ is the discretionary accruals (equation 1 ).

$$
\begin{gathered}
W C_{-} A C C_{i j t}=\beta_{0 i}+\beta_{1}\left(1 / A_{i j t-1}\right)+\beta_{2}\left(\Delta R E V_{i j t}-\Delta R E C_{i j t}\right)+\beta_{3}\left(P P E_{i j t}\right) \\
+\beta_{4}\left(W C_{-} A C C_{i j t-1}\right)+I F R S \exp _{j t}+\delta_{t}+\gamma_{s}+\theta_{j}+\varepsilon_{i j t}
\end{gathered}
$$

We estimate equation 1 with 66,603 firm-year observations and obtain an F statistic of $6.00(\mathrm{p}<0.01)$ and $\mathrm{R}^{2}$ of 0.7258 . Specifically, following other relevant studies (Doukakis, 2014; Enomoto et al., 2015), we define $|E M|_{\mathrm{ijt}}$ as the absolute value of discretionary accruals $\left(\varepsilon_{\mathrm{ijt}}\right)$, which indicates the magnitude of earnings management, regardless of whether it is positive or negative. This procedure captures the magnitude in each period, regardless of whether management increases or decreases the earnings of this period (the manager can manage earnings for more to increase his dividend distribution in this period or he can manage for less in a period with above-average earnings to form "earnings reserves" for future periods). We are interested in the firms that have managed more earnings, not how firms practice this management (whether to reduce or increase earnings).

\subsection{Earnings and Dividend Persistence}

To test $\mathrm{H}_{1}$, we estimate earnings persistence by using the Dechow and Schrand (2004) model (DS model). We estimate the original DS model to analyze the persistence of earnings and two modified versions based on the original model to estimate the equity's persistence and dividend persistence (equation 2).

$$
X_{i j t}=\beta_{0}+\beta_{1} X_{i j t-1}+\beta_{2} \operatorname{IFRSexp}_{j t-1}+\delta_{t}+\gamma_{s}+\theta_{j}+\varepsilon_{i j t}
$$

where for every firm $i$ in country $j$ and year $t, X_{\mathrm{ijt}}$ is the sales per share (model 1), the earnings per share (model
2 ), or the dividend per share (model 3 ) in year $t, X_{\mathrm{ijt}-1}$ is the sales per share (model 1 ), the earnings per share (model 2), or the dividend per share (model 3 ) in year $t-1$, IFRSExp $_{\mathrm{jt}-1}$ is the number of years of mandatory IFRS adoption, which can influence accounting information (Houqe $\&$ Monem, 2016), $\delta_{\mathrm{t}}, \gamma_{\mathrm{s}}$ and $\theta_{\mathrm{j}}$ are the fixed-effects, and $\varepsilon_{\mathrm{it}}$ is the idiosyncratic error of the model.

If the coefficient $\beta_{1}$ in equation 2 is close to 1 , it is easy to predict that the information of firms (equity, earnings, or dividends) is persistent in a standard asset valuation framework (Dechow et al., 2010; Dechow \& Schrand, 2004). Also, if dividends tend to be more persistent than earnings because firms tend to maintain their dividend volumes by only modifying the volume of profits distribution when earnings are volatile (Chan et al., 2018), we expect a larger coefficient for dividends than for earnings $\left(\beta_{1}^{D P S}>\beta_{1}^{E P S}\right)$.

\subsection{Dividend Persistence and Earnings Management}

Lintner (1956) argues that dividends tend to be more persistent than earnings because earnings are usually the starting point of management to consider whether dividends should change. Therefore, in addition to past dividends, Lintner (1956) notes that current earnings are a determinant of dividend persistence. In this sense, management has a greater influence on dividends than on earnings. To analyze $\mathrm{H}_{2}$, we use the Lintner model, as explained in equation 3 , which is commonly used in the literature. We estimate three modified versions 
of the model; one includes the effect of earnings management on dividends (equation 4), and the two other models interacting the effects of magnitude of earnings management with dividend persistence (the absolute value of $E M$ in equation 5, and the SD of $E M$ in equation 6).

$$
\begin{gathered}
D P S_{i j t}=\varnothing_{0}+\varnothing_{1} E P S_{i j t}+\varnothing_{2} D P S_{i j t-1}+\varnothing_{3} I \operatorname{RSPexp}_{j t-1}+\delta_{t}+\gamma_{s}+\theta_{j}+\varepsilon_{i j t} \\
D P S_{i j t}=\varnothing_{0}+\varnothing_{1} E P S_{i j t}+\varnothing_{2} D P S_{i j t-1}+\varnothing_{3} I F R \operatorname{Sexp}_{j t-1}+\varnothing_{4} E M_{i j t-1}+\delta_{t}+\gamma_{s}+\theta_{j}+\varepsilon_{i j t} \\
D P S_{i j t}=\varnothing_{0}+\varnothing_{1} E P S_{i j t}+\varnothing_{2} D P S_{i j t-1}+\varnothing_{3} I F R S \exp _{j t-1}+\varnothing_{4}|E M|_{i j t-1}+\varnothing_{5}\left(E P S_{i j t} \times|E M|_{i j t-1}\right)+ \\
\varnothing_{6}\left(D P S_{i j t-1} \times|E M|_{i j t-1}\right)+\delta_{t}+\gamma_{s}+\theta_{j}+\varepsilon_{i j t} \\
D P S_{i j t}=\varnothing_{0}+\varnothing_{1} E P S_{i j t}+\varnothing_{2} D P S_{i j t-1}+\varnothing_{3} I F R S \exp p_{j t-1}+\varnothing_{4} S D(E M)_{i j t-1}+\varnothing_{5}\left(E P S_{i j t} \times S D(E M)_{i j t-1}\right)+ \\
\varnothing_{6}\left(D P S_{i j t-1} \times S D(E M)_{i j t-1}\right)+\delta_{t}+\gamma_{s}+\theta_{j}+\varepsilon_{i j t}
\end{gathered}
$$

In these models, for every firm $i$ in country $j$ and year $t, D P S_{\mathrm{ijt}}$ is the dividend per share in year $t, E P S_{\mathrm{ijt}}$ are the earnings per share, $D P S_{\mathrm{it}-1}$ is the dividend per share in year $t-1$, and IFRSexp $\sin _{\mathrm{jt}-1}$ is the number of years of mandatory IFRS adoption. $E M_{\mathrm{ijt}-1}$ is the discretionary accruals estimated in equation 3 , and, alternatively, $|E M|_{\mathrm{ijt}-1}$ is the absolute value of discretionary accruals (Doukakis, 2014; Enomoto et al., 2015) and $S D(E M)_{\mathrm{ijt}-1}$ is the magnitude of the discretionary accruals, indicated by the SD (Choi et al., 2011). $\delta_{\mathrm{t}}, \gamma_{\mathrm{s}}$ and $\theta_{\mathrm{j}}$ are the fixed-effects, and $\varepsilon_{\text {it }}$ is the idiosyncratic error of the model.

The expectation for the Lintner model is that the coefficient of dividend persistence should be positive and significant $\left(\varnothing_{2}>0\right)$, i.e., that the dividend paid in year $t-1\left(D P S_{\mathrm{ijt}-1}\right)$ explains the dividends paid in the current year $\left(D P S_{\mathrm{ijt}}\right)$, just as $E P S_{\mathrm{ijt}}$ should positively influence $D P S_{\mathrm{ijt}}\left(\varnothing_{3}>0\right)$. When earnings are manipulated, both current and future earnings are affected (Martinez, 2008), and corporate managers tend to manage their earnings, especially when they are below expected dividend levels (Daniel et al., 2008). Therefore, we expect a negative and significant interaction coefficient $\left(\varnothing_{6}<0\right)$.

\subsection{Dividend Persistence and the Characteristics of Countries}

Finally, we analyze the effects of countries' characteristics on dividend persistence, specifically GDP growth $\left(\mathrm{H}_{3}\right)$ and sovereign risk $\left(\mathrm{H}_{4}\right)$, according to equations 7 and 8 . A country's economic performance can also affect the quality of accounting information (Silva et al., 2014) and modify a country's perception of risk because of fluctuations and unpredictability in firms' performance variables, especially in emerging countries where there is more macroeconomic volatility (Malik \& Temple, 2009). Therefore, it is natural to expect that earnings and dividends are influenced by these variables.

Thus, we consider that macroeconomic volatility reflects fluctuations and unpredictability in the firms' performance (Malik \& Temple, 2009), especially in emerging countries, where there is usually more volatility in the country's economic performance and where the country's GDP is lower (Dimitras et al., 2015). Still, the change in the degree of a country's sovereign risk can affect the volume of dividends paid as a means of improving a firm's reputation and reducing investor risk (La Porta et al., 2000).

$$
\begin{aligned}
D P S_{i j t}= & \varnothing_{0}+\varnothing_{1} E P S_{i j t}+\varnothing_{2} D P S_{i j t-1}+\varnothing_{3} I F R S \exp _{j t-1}+\varnothing_{4} G D P_{j t-1}+\varnothing_{5}\left(E P S_{i j t} \times G D P_{j t-1}\right)+ \\
& \varnothing_{6}\left(D P S_{i j t-1} \times G D P_{j t-1}\right)+\varnothing_{7}\left(\operatorname{IFRSexp}_{j t-1} \times G D P_{j t-1}\right)+\delta_{t}+\gamma_{s}+\theta_{j}+\varepsilon_{i j t} \\
D P S_{i j t}= & \varnothing_{0}+\varnothing_{1} E P S_{i j t}+\varnothing_{2} D P S_{i j t-1}+\varnothing_{3} I F R S \operatorname{Sexp}_{j t-1}+\varnothing_{4} S R I_{j t-1}+\varnothing_{5}\left(E P S_{i j t} \times S R I_{j t-1}\right)+ \\
& \varnothing_{6}\left(D P S_{i j t-1} \times S R I_{j t-1}\right)+\varnothing_{7}\left(\operatorname{IFRSexp}_{j t-1} \times S R I_{j t-1}\right)+\delta_{t}+\gamma_{s}+\theta_{j}+\varepsilon_{i j t}
\end{aligned}
$$


where for every firm $i$ in country $j$ and year $t, G D P_{\mathrm{jt}-1}$ is the percentage of GDP between years $t-2$ and $t-1$, and $S R I_{\mathrm{jt}-1}$ is the sovereign risk indicator of the country. The DPS, EPSI, and IFRSexp variables as previously defined. The $\delta_{\mathrm{t}}, \gamma_{\mathrm{s}}$, and $\theta_{\mathrm{j}}$ are the fixed-effects, and $\varepsilon_{\mathrm{ijt}}$ is the error term. We expect the coefficients $\varnothing_{1}$ and $\varnothing_{2}$ to be positive (Lintner, 1956). The coefficient of GDP growth should be positive and significant $\left(\varnothing_{4}^{G D P}>0\right)$, which associates the dividend growth with the emerging country's economy growth (Dimitras et al., 2015). We expect that dividend persistence will be greater in countries with higher GDP growth $\left(\varnothing_{6}^{G D P}>0\right)$.
Regarding sovereign risk, there is a possibility that dividends will be reduced when the emerging country is in a financial crisis or even continually changes its dividend policy when there is a greater risk (Marsh \& Merton, 1987). Therefore, there is no clear direction in the relationship between SRI and dividends paid. However, dividend persistence in emerging countries with a lower sovereign risk tends to be greater due to the greater stability of the firms' earnings and lower volatility of the dividends (Chan et al., 2018). Therefore, we expect a positive effect of SRI on dividend persistence $\left(\varnothing_{6}^{S R I}>0\right)$.

\section{RESULTS}

Our findings show that, on average, a typical company in the sample has an annual sales per share (SPS) of USD 12.36, an annual earnings per share (EPS) of USD 0.49 , an annual dividend per share (DPS) of USD 0.12, and a dividend payout ratio (DP) of $25.91 \%$. The mean of discretionary accruals is 0.0309 , which represents a firm's earnings management. We can note the presence of negative EPS (USD -3.59) among the firms, which culminates in an extremely negative dividend payout and reaches a minimum value of $-152.84 \%$.

We observe that the lowest annual accrual is -0.6415 , and the highest is 0.5705 , which indicates that firms tend to manage their results for less or more, with a trend of a reversal of accruals in the following periods, as noted by Dechow et al. (2010). For this reason, in the estimated models, the discretionary accruals volume and SD are considered, regardless of whether management is down or up. The mean of the return on equity (ROE) is $10.58 \%$, which considers only the firms with positive equity. The mean of the market-to-book (MB) is 1.79 , which indicates that the emerging market firms have a market value higher than their book value. The mean of the firms' leverage of 0.68 indicates that firms use debt in the proportion of 0.68 times their equity. Furthermore, the average firm's size is USD 944 million.

Regarding country indicators, we can note, in Table 1, that the average years of the full IFRS experience of the countries are 1.07 years, which considers all countries (including the countries that have not yet adopted the full IFRS). The country with the most IFRS experience has 13 years of experience, and there is a country that has not adopted IFRS. The annual average of GDP growth is $4.60 \%$, and the average of the country sovereign risk (SRI) score is 10.99 , which is equivalent to the grade of "A-". This score was based on Oshiro and Saruwatari (2005) and coded as follows: $\mathrm{AAA}=17 ; \mathrm{AA}+=16$; $\mathrm{AA}$ $=15 ; \mathrm{AA}-=14 ; \ldots ; \mathrm{BB}=6 ; \mathrm{BB}-=5 ; \mathrm{B}+=4 ; \mathrm{B}=3 ; \mathrm{B}-=$ $2 ; \mathrm{CCC}+=1$; and $\mathrm{CCC}$ and under $=0$.

Table 1

Descriptive statistics, 2000-2016

\begin{tabular}{lcccccc}
\hline Variable & \#Obs. & Mean & $\begin{array}{l}\text { Standard } \\
\text { deviation }\end{array}$ & Median & Minimum & Maximum \\
\hline SPS & 68,038 & 12.3612 & 39.9582 & 1.9121 & 0.0033 & 301.3166 \\
\hline EPS & 68,038 & 0.4889 & 1.9028 & 0.0853 & -3.5907 & 13.8845 \\
\hline DPS & 68,038 & 0.1214 & 0.3426 & 0.0195 & 0.0001 & 2.4865 \\
\hline$D P$ & 68,038 & 25.9126 & 60.5874 & 10.9986 & -152.8434 & 399.1587 \\
\hline$D A$ & 66,603 & 0.0309 & 0.2128 & 0.0349 & -0.6415 & 0.5705 \\
\hline ROE & 68,038 & 10.5832 & 24.5983 & 9.4162 & -83.3804 & 102.2957 \\
\hline MB & 68,038 & 1.7883 & 2.0261 & 1.1521 & 0.1241 & 13.2586 \\
\hline Lev & 68,038 & 0.6775 & 0.9627 & 0.3772 & 0.0000 & 6.1626 \\
\hline Size & 68,038 & 944.0000 & $2,820.0000$ & 130.0000 & 3.3542 & $20,200.0000$ \\
\hline IFRSexp & 68,038 & 1.0660 & 2.2407 & 0.0000 & 0.0000 & 13.0000 \\
\hline
\end{tabular}


Table 1

Cont.

\begin{tabular}{lcccccc}
\hline Variable & \#Obs. & Mean & $\begin{array}{l}\text { Standard } \\
\text { deviation }\end{array}$ & Median & Minimum & Maximum \\
\hline$G D P$ & 68,038 & 4.6030 & 3.2189 & 4.1000 & -9.1325 & 26.1703 \\
\hline$S R I$ & 68,038 & 10.9889 & 3.0043 & 12.0000 & 0.0000 & 15.0000 \\
\hline
\end{tabular}

Note: For every firm $i$ in country $j$ and year $t, S P S_{i j t}$ are the sales per share, $E P S_{i j t}$ are the earnings per share, DPS ijt is the dividend per share, $D P_{i j t}$ is the dividend payout ratio, which is represented by the percentage of distributed earnings, $D A_{i j t}$ is the discretionary accrual, $R O E_{i j t}$ is the return on equity, $M B_{i j t}$ is the market-to-book index, Levijt is the leverage, which is represented by the debt-to-equity ratio, Size ${ }_{i j t}$ is the total sales (in millions of dollars), IFRSexp ist $_{\text {it }}$ the number of years since the mandatory International Financial Reporting Standards (IFRS) adoption of each country, GDP $P_{\text {jt }}$ is the percentage of the gross domestic product (GDP) growth, and SRI $I_{j t}$ is the sovereign risk indicator for each country from Standard \& Poor's.

Source: Elaborated by the authors.

The means of the analyzed variables in the entire sample are different among countries, which justifies the inclusion of controls for years, industry, and country in the estimated models and the use of clusters at the firm level. Among the 20 countries analyzed, South Korea (25.5\%), India (24.9\%), and Taiwan $(24.1 \%)$ are the most representative countries, while each of the other countries represents less than $4 \%$ of the analyzed sample. For this reason, we did additional tests excluding India, South Korea, and Taiwan from the analysis to see if these countries were conducting our results and found that the findings for this subsample are similar. This can be seen in Table 5 (reported later), which shows individual results by country, and in tables A, B and C of the Appendix. As the findings do not change, we do not detail this analysis to save space.

The Czech Republic is the country with the highest average $\overline{S P S}$ (USD 51.02), $\overline{E P S}$ (USD 0.44) and $\overline{D P S}$ (USD 1.44) because in the analyzed sample, the firms in this country have the lowest number of shares outstanding. In contrast, lower averages of $\overline{S P S}$ (USD 0.48), $\overline{E P S}(0.04)$, and $\overline{D P S}$ (USD 0.01) are observed in China, which presents a higher number of shares outstanding. The highest averages of distributed profits are observed in the Czech Republic $(\overline{D P}=63.8 \%)$ and Colombia $(\overline{D P}=60 \%)$. The countries with the lowest payout dividends are India (14.5\%) and
South Korea (16.2\%). Regarding earnings management, the country in which the firms managed their earnings most negatively from 2000 to 2016 was Brazil $(\overline{E M}=$ -0.4831), while South Africa showed the highest positive management $(\overline{E M}=0.1427)$.

Concerning firm characteristics, companies from South Africa have the highest average ROE (26.1\%), and firms with the lowest $\overline{R O E}$ are from Greece (3.7\%). Arab companies have the highest $M B$ average (2.89), and Colombian firms have the lowest average $M B(1.20)$. The firms with the highest average level of leverage are from Greece, with debts equivalent to 1.15 times their equity $(\overline{L e v}=1.15)$, while the least leveraged companies are in the Czech Republic $(\overline{L e v}=0.37)$. Regarding firms' size, Russia has larger firms with an average total sales of USD 6,070 million, while Egypt has smaller companies with an average total sales equivalent to USD 445 million, according to Table 2 .

The country characteristics show that four of the 20 countries analyzed have not yet adopted the full IFRS. In this sample, the first country to promote mandatory IFRS adoption is Qatar in 2003, and the last country is Colombia in 2015. Considering the average annual $\overline{G D P}$ growth, Qatar shows the highest average $(9.8 \%)$, followed by China (8.7\%), and India (7.3\%). Greece is the only country with an average negative $\overline{G D P}$ growth $(-1.8 \%)$.

Table 2

Means of the analyzed variables by country, 2000-2016

\begin{tabular}{lccccccccccccc}
\hline Country & \#Obs. & SPS & EPS & DPS & D/E & EM & ROE & MB & Lev & Size & IFRS & GDP & SRI \\
\hline Brazil & 1,648 & 18.1490 & 0.7160 & 0.3190 & 32.7057 & -0.4831 & 13.0374 & 2.2506 & 0.9946 & $3,370.00$ & 2010 & 2.0282 & 7.6044 \\
\hline Chile & 1,691 & 11.5654 & 0.4319 & 0.1722 & 44.0173 & 0.1374 & 7.2014 & 1.5970 & 0.4990 & $1,770.00$ & 2011 & 3.9172 & 12.8865 \\
\hline China & 2,605 & 0.4767 & 0.0359 & 0.0108 & 22.1020 & 0.0171 & 15.8223 & 2.0475 & 0.5131 & $1,820.00$ & None & 8.6835 & 13.3866 \\
\hline Colombia & 167 & 4.5544 & 0.4383 & 0.1653 & 60.0116 & -0.0088 & 8.5317 & 1.1950 & 0.4798 & $3,690.00$ & 2015 & 4.1608 & 8.3174 \\
\hline $\begin{array}{l}\text { Czech } \\
\text { Republic }\end{array}$ & 77 & 51.0194 & 5.2681 & 1.4439 & 63.8157 & -0.3376 & 15.2107 & 1.5572 & 0.3698 & $4,650.00$ & 2005 & 2.6685 & 12.6623 \\
\hline Egypt & 653 & 4.4683 & 0.4067 & 0.2136 & 57.0204 & -0.0058 & 19.0925 & 1.9874 & 0.4604 & 445.00 & None & 4.0534 & 4.6064 \\
\hline
\end{tabular}


Table 2

Cont.

\begin{tabular}{|c|c|c|c|c|c|c|c|c|c|c|c|c|c|}
\hline Country & \#Obs. & SPS & EPS & DPS & $D / E$ & EM & ROE & MB & Lev & Size & IFRS & GDP & SRI \\
\hline Greece & 1,360 & 11.9468 & 0.3167 & 0.1598 & 20.5733 & -0.0098 & 3.7449 & 1.2856 & 1.1471 & 860.00 & 2005 & -1.8133 & 6.9059 \\
\hline Hungary & 192 & 15.4603 & 1.0240 & 0.3279 & 22.4079 & 0.0139 & 8.3577 & 1.6811 & 0.4937 & $1,800.00$ & 2005 & 1.6042 & 8.6042 \\
\hline India & 5,997 & 4.2626 & 0.2738 & 0.0454 & 14.4820 & 0.1225 & 16.7916 & 2.0742 & 0.9882 & 602.00 & None & 7.3365 & 7.7267 \\
\hline Mexico & 840 & 4.0249 & 0.1965 & 0.0473 & 24.1125 & -0.0036 & 11.0392 & 1.9950 & 0.6896 & $2,810.00$ & 2012 & 2.1188 & 9.2190 \\
\hline Peru & 149 & 1.7061 & 0.3978 & 0.1108 & 49.4309 & 0.0213 & 23.2118 & 2.1870 & 0.5939 & 691.00 & 2012 & 4.8416 & 8.4430 \\
\hline Poland & 2,727 & 16.2175 & 0.6446 & 0.1847 & 25.7407 & 0.0151 & 11.4268 & 1.9151 & 0.4284 & 513.00 & 2005 & 3.6068 & 10.7422 \\
\hline Qatar & 173 & 7.7609 & 1.4928 & 0.7810 & 52.4016 & -0.0076 & 20.1953 & 2.3238 & 0.6670 & $3,230.00$ & 2003 & 9.7992 & 14.6127 \\
\hline Russia & 768 & 17.9009 & 1.4773 & 0.2917 & 22.4896 & -0.0069 & 15.1227 & 1.7973 & 0.9389 & $6,070.00$ & 2012 & 2.3933 & 8.4570 \\
\hline $\begin{array}{l}\text { Saudi } \\
\text { Arabia }\end{array}$ & 867 & 4.3437 & 0.5617 & 0.3656 & 53.8962 & 0.0058 & 15.3089 & 2.8888 & 0.4427 & $2,040.00$ & None & 4.0385 & 13.3460 \\
\hline $\begin{array}{l}\text { South } \\
\text { Africa }\end{array}$ & 1,176 & 4.6016 & 0.4242 & 0.1296 & 25.4345 & 0.1427 & 26.1367 & 2.6134 & 0.4958 & $1,160.00$ & 2012 & 2.7782 & 9.1879 \\
\hline $\begin{array}{l}\text { South } \\
\text { Korea }\end{array}$ & 17,367 & 33.9741 & 1.1302 & 0.2202 & 16.1804 & 0.0136 & 29 & 1.3775 & 0.6357 & 0 & 2014 & 3.7310 & 12.3844 \\
\hline Taiwan & 16,402 & 1.1562 & 0.0432 & 0.0368 & 42.2559 & 0.0074 & 7.9556 & 1.7387 & 0.4573 & 555.00 & 2013 & 3.4191 & 14.0117 \\
\hline Turkey & 1,766 & 5.2233 & 0.2857 & 0.1436 & 30.7768 & 0.0164 & 9.5652 & 1.8845 & 0.5716 & 865.00 & 2005 & 5.3708 & 5.6586 \\
\hline $\begin{array}{l}\text { United } \\
\text { Arab } \\
\text { Emirates }\end{array}$ & 413 & 1.6704 & 0.0739 & 0.0379 & 41.8956 & -0.0042 & 11.0379 & 1.5332 & 0.5534 & $2,120.00$ & 2015 & 3.6419 & 14.8450 \\
\hline Total & 68,038 & 12.3612 & 0.4889 & 0.1214 & 25.9126 & 0.0309 & 10.5832 & 1.7883 & 0.6775 & 944.0000 & - & 4.6030 & 10.9889 \\
\hline
\end{tabular}

Note: \#Obs. is the total number of observations, SPS is the sales per share, EPS is the earnings per share, DPS is the dividend per share, D/E is the dividend payout ratio, which is represented by the percentage of distributed earnings, EM is the earnings management, ROE is the return on equity, MB is the market-to-book index, Lev is the leverage, Size is the total sales (in millions of dollars), IFRS indicates the year in which the full International Financial Reporting Standards (IFRS) became mandatory, GDP is the percentage of the gross domestic product (GDP) growth, and SRI is the sovereign risk indicator from Standard \& Poor's.

Source: Elaborated by the authors.

In eight of the 17 analyzed years, the Greek GDP decreased, with the most marked falls in 2011 and $2012(-9.1 \%$ and $-7.3 \%$, respectively). The country with the highest SRI average is the United Arab Emirates $(\overline{S R I}=14.85)$, which indicates a lower risk, while Egypt has the lowest average score of the period $(\overline{S R I}=4.61)$, which indicates high risk. In countries with the worse economic performance or higher risks, firms tend to pay more dividends (Dimitras et al., 2015; Marsh \& Merton, 1987). Finally, we can see in Table 2 that $74.6 \%$ of the observations are concentrated in three countries (South Korea, India and Taiwan). For this reason, we estimate individual models for that group of countries, to make sure that our findings are not driven by them (see Appendix).

To verify the level of association between the variables, we analyze their correlation coefficients, which are presented in Table 3. The increase in sales is positively associated with the increase in earnings (0.6492) and the increase in dividends (0.6124). On the one hand, it is natural that more profitable firms show higher sales growth and that there is an increase in the distribution of earnings to shareholders (Jabbouri, 2016). On the other hand, the increase in sales is negatively associated with the increase of dividend payout (-0.0311), which is typical, given that usually, the increase in sales represents a firm's growth and to grow, firms need to distribute fewer profits, which results in a lower payout ratio (Jabbouri, 2016). Also, in the analyzed period, discretionary accruals have a negative relation to sales (-0.0448), earnings (-0.0307), and dividends (-0.1008), which indicate that firms that manage their earnings tend to have lower sales, tend to be less profitable, and tend to distribute fewer dividends.

The increase in sales is negatively associated with $R O E$ $(-0.0066)$, while the increase in earnings is positively associated with the increase in dividends (0.2418). The increase in $R O E$ is also positively associated with the increase in dividends (0.1124) and with the dividend payout $(0.0634)$. These findings are consistent with Jabbouri (2016). The increase in $M B$ is positively related 
to increases in earnings (0.0093) and dividends (0.0471). In contrast, an increase in leverage is negatively associated with earnings (-0.1150) and dividends (-0.0721), given that higher leverage leads to a higher financial expense and lower earnings volume, according to Al-Kuwari (2009). Additionally, firms with a larger size tend to have higher equity (0.1784), earnings $(0.1755)$, dividends $(0.2088)$, and $D P$ ratios (0.0148).

Table 3

Correlation matrix of the analyzed variables, 2000-2016

\begin{tabular}{|c|c|c|c|c|c|c|c|c|c|c|c|}
\hline Variables & $S P S_{i j t}$ & $E P S_{i j t}$ & $D P S_{i j t}$ & $D / E_{i j t}$ & $E M_{i j t}$ & $R O E_{i j t}$ & $M B_{i j t}$ & $L e v_{i j t}$ & Size $_{i j t}$ & IFRSexp $j t$ & $G D P_{j t}$ \\
\hline$E P S_{\mathrm{ijt}}$ & $0.6492^{* * *}$ & & & & & & & & & & \\
\hline$D P S_{i j t}$ & $0.6124^{* * *}$ & $0.6822^{* * *}$ & & & & & & & & & \\
\hline$D / E_{\mathrm{ijt}}$ & $-0.0311^{* * *}$ & $0.0082^{* * *}$ & $0.1342^{* * *}$ & & & & & & & & \\
\hline$E M_{\mathrm{ijt}}$ & $-0.0448^{* * *}$ & $-0.0307^{* * *}$ & $-0.1008^{* * *}$ & $-0.0458^{* * *}$ & & & & & & & \\
\hline$R O E_{i j t}$ & $-0.0066^{* * *}$ & $0.2418^{* * *}$ & $0.1124^{* * *}$ & $0.0634^{* * *}$ & $0.1327^{* * *}$ & & & & & & \\
\hline$M B_{i \mathrm{itt}}$ & $-0.0546^{* * *}$ & $0.0093^{* * *}$ & $0.0471^{* * *}$ & $-0.0015^{* * *}$ & $0.1077^{* * *}$ & $0.2142^{* * *}$ & & & & & \\
\hline$L e v_{i j t}$ & $-0.0596^{* * *}$ & $-0.1150^{* * *}$ & $-0.0721^{* * *}$ & $-0.1055^{* * *}$ & $-0.0418^{* * *}$ & $-0.2557^{* * *}$ & $0.0557^{* * *}$ & & & & \\
\hline Size $_{i j t}$ & $0.1908^{* * *}$ & $0.1755^{* * *}$ & $0.2088^{* * *}$ & $0.0148^{* * *}$ & $-0.1374^{* * *}$ & $0.0453^{* * *}$ & $-0.0084^{* * *}$ & $0.0979^{* * *}$ & & & \\
\hline IFRSExp $_{\mathrm{jt}}$ & $0.0037^{* * *}$ & $0.0169^{* * *}$ & $0.0771^{* * *}$ & $0.0267^{* * *}$ & $-0.1752^{* * *}$ & $-0.0293^{* * *}$ & $0.0202^{* * *}$ & $-0.0349^{* * *}$ & $0.0271^{* * *}$ & & \\
\hline$G D P_{\mathrm{jt}}$ & $-0.0652^{* * *}$ & $-0.0209^{* * *}$ & $-0.0738^{* * *}$ & $-0.0685^{* * *}$ & $0.2646^{* * *}$ & $0.1725^{* * *}$ & $0.1104^{* * *}$ & $0.0437^{* * *}$ & $-0.0327^{* * *}$ & $-0.2342^{* * *}$ & \\
\hline$S \boldsymbol{R} \boldsymbol{I}_{\mathrm{jt}}$ & $0.0490^{* * *}$ & $0.0192^{* * *}$ & $0.0170^{* * *}$ & $0.0974^{* * *}$ & $-0.0833^{* * *}$ & $-0.1246^{* * *}$ & $-0.0522^{* * *}$ & $-0.1790^{* * *}$ & $-0.0140^{* * *}$ & $-0.0633^{* * *}$ & $-0.2136^{* * *}$ \\
\hline
\end{tabular}

Note: For every firm $i$ in country $j$ and year $t, S P S_{i j t}$ are the sales per share, EPS $i j t$ are the earnings per share, DPS $i j t$ is the dividend per share, $D / E_{i j t}$ is the dividend payout ratio, which is represented by the percentage of distributed earnings, $E M_{i j t}$ is the earnings management, $R O E_{i j t}$ is the return on equity, $M B_{i j t}$ is the market-to-book index, Levijt is the leverage, Size iijt is the firm's size, which is represented by the logarithm of total sales, IFRSexp jt $_{\text {is }}$ the number of years since the mandatory International Financial Reporting Standards (IFRS) adoption of each country, GDP jt is the percentage of the gross domestic product (GDP) growth, and SRI it is the sovereign risk indicator for each country from Standard \& Poor's.

**, ${ }^{* * *}=$ significant at 5 and $1 \%$, respectively.

Source: Elaborated by the authors.

Regarding country characteristics, IFRS experience is positively associated with increased earnings (0.0169) and negatively associated with discretionary accruals $(-0.1752)$. This result indicates that the firms in the analyzed emerging countries show a greater trend of negative accruals, which is explained by the creation of "earnings reserves" by firms when their results are higher than expected to be compensated in future periods, when possible results are below expectations (Dechow \& Schrand, 2004). Nevertheless, this is consistent with Ismail et al. (2013), who observe that the mandatory IFRS tends to decrease earnings management.

A country's GDP growth is negatively associated with dividend growth $(-0.0738)$ and the $D P$ ratio $(-0.0685)$, which suggests that, in periods of higher growth in a country's economy, firms tend to retain more profits to support their growth. This is consistent with the positive association of GDP growth with corporate leverage (0.0437), which indicates that firms also seek more debt to finance their growth. These findings are consistent with the results identified by Dimitras et al. (2015) for Ireland. Lastly, higher SRI scores are positively associated with higher dividends (0.0170) and a higher $D P$ ratio (0.0974).

Testing the first hypothesis of this study $\left(\mathrm{H}_{1}\right)$, Table 4 presents the findings where dividends are more persistent than earnings. For this analysis, we use the DS model, where the authors predicted an earnings persistence coefficient of 0.71 for a sample of firms in the United States of America a developed country, from 1987 to 2002. In their analysis, Dechow and Schrand (2004) also present sales persistence, with a coefficient of 0.85 .

Table 4 presents the coefficients estimated in this study for the persistence of SPS, EPS, and DPS in emerging countries. Model 1 shows that past sales are positively and significantly associated with current sales $\left(\beta_{1}^{\text {SPS }}=\right.$ 0.9441 ), which indicates sales persistence. This means that if a company earns USD 1.00 of sales, then, on average, 94 cents will persist into next year's sales. This coefficient is greater than the coefficient observed years ago by Dechow and Schrand (2004) for the firms in a developed country (0.84).

Regarding earnings, model 2 demonstrates that past earnings present a positive and significant association with 
present earnings ( $\left.\beta_{1}^{E P S}=0.7561\right)$. This means the earnings persistence among companies in emerging countries, where if a company earns USD 1.00 of earnings, then, on average, 76 cents will persist into next year's earnings. As in Dechow and Schrand (2004), this coefficient is lower than the sales coefficient; however, the coefficient of earnings found in this study is higher than the coefficient observed in the Dechow and Schrand study. Also, model 3 reveals that dividends are indeed persistent $\left(\beta_{1}^{E P S}=\right.$ 0.8912 ) and demonstrates that if a company pays USD 1.00 of dividends, then, on average, 89 cents will persist into next year's dividends.
By continuing to examine Table 4 and comparing the estimated models for the same sample, we can verify that, in fact, in emerging markets, dividends are more persistent than earnings $\left(\beta_{1}^{D P S}>\beta_{1}^{E P S}\right)$. This finding confirms $\mathrm{H}_{1}$, which is consistent with Chan et al. (2018), who argue that dividends are more smoothed than earnings. We add this evidence of the proportion of sales and earnings persistence, and we present new evidence of the dividend persistence in emerging countries. Thus, we demonstrate that these recent findings for emerging markets are larger than the results found in the US market by Dechow and Schrand (2004).

Table 4

Regressions for sales, earnings, and dividend persistence, 2000-2016

\begin{tabular}{|c|c|c|c|}
\hline Variable & Model 1 (SPS) & Model 2 (EPS) & Model 3 (DPS) \\
\hline$\left(\beta_{0}\right)$ Constant & $\begin{array}{c}-1.2993^{* *} \\
(0.5378)\end{array}$ & $\begin{array}{l}-0.0765 \\
(0.0580)\end{array}$ & $\begin{array}{c}0.0234 * * * \\
(0.0087)\end{array}$ \\
\hline$\left(\beta_{1}\right) X_{\mathrm{it}-1}$ & $\begin{array}{c}0.9441^{* * *} \\
(0.0054)\end{array}$ & $\begin{array}{c}0.7561^{* * *} \\
(0.0148)\end{array}$ & $\begin{array}{c}0.8912^{* * *} \\
(0.0088)\end{array}$ \\
\hline$\left(\beta_{2}\right)$ IFRSexp $\operatorname{ext}_{\mathrm{t}-1}$ & $\begin{array}{c}0.0271 \\
(0.0358)\end{array}$ & $\begin{array}{c}0.0075^{* *} \\
(0.0034)\end{array}$ & $\begin{array}{c}0.0026^{* * *} \\
(0.0007)\end{array}$ \\
\hline$\left(\delta_{\mathrm{t}}\right)$ Year dummies & Yes & Yes & Yes \\
\hline$\left(\gamma_{\mathrm{s}}\right)$ Industry dummies & Yes & Yes & Yes \\
\hline$\left(\theta_{\mathrm{j}}\right)$ Country dummies & Yes & Yes & Yes \\
\hline F statistic & $2,064.93^{* * *}$ & $219.29^{* * *}$ & $687.57^{* * *}$ \\
\hline Adjusted $\mathrm{R}^{2}$ & 0.9367 & 0.5967 & 0.7731 \\
\hline Firms & 7,536 & 7,536 & 7,536 \\
\hline Observations & 68,038 & 68,038 & 68,038 \\
\hline
\end{tabular}

Note: This table shows the coefficient estimates and standard errors (in parentheses) from the ordinary least squares (OLS) regressions. Errors are clustered at the firm level and the estimation of standard errors is robust to heteroscedasticity and the firm-, industry-, and country-level error correlations. For every firm i in country $j$ and year $t$, $X$ is the sales per share (model 1), the earnings per share (model 2) or the dividend per share (model 3), IFRSexp is the number of years of mandatory International Financial Reporting Standards (IFRS) adoption, and $\delta_{t}, \gamma_{s}$, and $\theta_{j}$ represent the year, industry, and country fixed-effects, respectively.

**, ${ }^{* * *}=$ significant at 5 and $1 \%$, respectively.

Source: Elaborated by the authors.

As a robustness analysis, we excluded South Korea, India, and Taiwan from the sample, individually and together, and found, in general, that the coefficients $\beta_{1}$ of the models in Table 4 remain positive and significant (see Table A in the Appendix). However, to detail the analysis at the country level, equation 4 is re-estimated for each country in Table 5. Note that the only exception is China, in all other countries the results remain (positive and significant coefficients), whether for SPS, EPS, or DPS.
This confirms the conclusion that the study's findings are not conducted by South Korea, India, and Taiwan.

Table 5 shows that, in all other emerging countries, the DS models estimated for sales, earnings, and dividends confirm the persistenceidentified in the full models (Table 4) at conventional statistical levels. Except for China, in fact, in all other countries, the sales persistence coefficient is greater than the earnings persistence coefficient $\left(\beta_{1}^{S P S}>\beta_{1}^{E P S}\right)$. 
Table 5

Regressions for equity, earnings, and dividend persistence by country, 2000-2016

\begin{tabular}{|c|c|c|c|c|}
\hline Country & Sample & Model 1 (SPS) & Model 2 (EPS) & Model 3 (DPS) \\
\hline Brazil & $\begin{array}{c}i=190 \\
n=1,648\end{array}$ & $\begin{array}{c}0.8929 * * * \\
(0.8851)\end{array}$ & $\begin{array}{c}0.5820^{* * *} \\
(0.3113)\end{array}$ & $\begin{array}{c}0.7614^{* * *} \\
(0.5685)\end{array}$ \\
\hline Chile & $\begin{array}{c}i=137 \\
n=1,691\end{array}$ & $\begin{array}{c}0.9849 * * * \\
(0.9773)\end{array}$ & $\begin{array}{c}0.7978^{* * *} \\
(0.5229)\end{array}$ & $\begin{array}{c}0.8216^{* * *} \\
(0.5813)\end{array}$ \\
\hline China & $\begin{array}{c}i=392 \\
n=2,605\end{array}$ & $\begin{array}{c}0.0837 \\
(0.0620)\end{array}$ & $\begin{array}{c}0.1723 \\
(0.0653)\end{array}$ & $\begin{array}{c}0.1008^{* * *} \\
(0.0157)\end{array}$ \\
\hline Colombia & $\begin{array}{c}i=32 \\
n=167\end{array}$ & $\begin{array}{c}1.0160^{* * *} \\
(0.9810)\end{array}$ & $\begin{array}{c}1.0041^{* * *} \\
(0.9926)\end{array}$ & $\begin{array}{c}0.9852^{* * *} \\
(0.8980)\end{array}$ \\
\hline Czech Republic & $\begin{array}{c}i=7 \\
n=77\end{array}$ & $\begin{array}{c}0.9119 * * * \\
(0.9656)\end{array}$ & $\begin{array}{c}0.9058^{* * *} \\
(0.8683)\end{array}$ & $\begin{array}{c}0.9175^{* * * *} \\
(0.8474)\end{array}$ \\
\hline Egypt & $\begin{array}{c}i=78 \\
n=653\end{array}$ & $\begin{array}{c}0.9282^{* * *} \\
(0.8853)\end{array}$ & $\begin{array}{c}0.7962^{* * *} \\
(0.6913)\end{array}$ & $\begin{array}{c}0.8023^{* * *} \\
(0.6646)\end{array}$ \\
\hline Greece & $\begin{array}{c}i=157 \\
n=1,360\end{array}$ & $\begin{array}{c}0.8975^{* * *} \\
(0.8200)\end{array}$ & $\begin{array}{c}0.5987^{* * *} \\
(0.4060)\end{array}$ & $\begin{array}{c}0.7904^{* * *} \\
(0.5702)\end{array}$ \\
\hline Hungary & $\begin{array}{c}i=22 \\
n=192\end{array}$ & $\begin{array}{c}0.9408^{* * *} \\
(0.9378) \\
\end{array}$ & $\begin{array}{c}0.8543^{* * *} \\
(0.7068)\end{array}$ & $\begin{array}{c}0.7450^{* * *} \\
(0.8364)\end{array}$ \\
\hline India & $\begin{array}{c}i=2,079 \\
n=16,997\end{array}$ & $\begin{array}{c}0.8927^{* * *} \\
(0.8410)\end{array}$ & $\begin{array}{c}0.7563 * * * \\
(0.5236)\end{array}$ & $\begin{array}{c}0.7187^{* * *} \\
(0.4759)\end{array}$ \\
\hline Mexico & $\begin{array}{c}i=82 \\
n=860\end{array}$ & $\begin{array}{c}0.9526^{* * *} \\
(0.9769) \\
\end{array}$ & $\begin{array}{c}0.9537^{* * *} \\
(0.8776) \\
\end{array}$ & $\begin{array}{c}0.5884^{* * *} \\
(0.2180) \\
\end{array}$ \\
\hline Peru & $\begin{array}{c}i=27 \\
n=149\end{array}$ & $\begin{array}{c}0.9855^{* * *} \\
(0.9511) \\
\end{array}$ & $\begin{array}{c}0.9687^{* * *} \\
(0.2477) \\
\end{array}$ & $\begin{array}{c}0.4326^{* *} \\
(0.0518)\end{array}$ \\
\hline Poland & $\begin{array}{c}i=346 \\
n=2,727\end{array}$ & $\begin{array}{c}0.9719 * * * \\
(0.9077)\end{array}$ & $\begin{array}{c}0.8393^{* * *} \\
(0.6565)\end{array}$ & $\begin{array}{c}0.8929 * * * \\
(0.6917)\end{array}$ \\
\hline Qatar & $\begin{array}{c}i=20 \\
n=173\end{array}$ & $\begin{array}{c}1.0449 * * * \\
(0.9365)\end{array}$ & $\begin{array}{c}0.9149 * * * \\
(0.7072)\end{array}$ & $\begin{array}{c}0.8625^{* * *} \\
(0.6134)\end{array}$ \\
\hline Russia & $\begin{array}{l}i=107 \\
n=768\end{array}$ & $\begin{array}{c}0.9505^{* * *} \\
(0.8897)\end{array}$ & $\begin{array}{c}0.8680 * * * \\
(0.7330)\end{array}$ & $\begin{array}{c}0.9121^{* * *} \\
(0.7059)\end{array}$ \\
\hline Saudi Arabia & $\begin{array}{l}i=112 \\
n=867\end{array}$ & $\begin{array}{c}1.0138^{* * *} \\
(0.8971)\end{array}$ & $\begin{array}{c}0.8790^{* * *} \\
(0.6143)\end{array}$ & $\begin{array}{c}0.8938^{* * *} \\
(0.7337)\end{array}$ \\
\hline South Africa & $\begin{array}{c}i=138 \\
n=1,176\end{array}$ & $\begin{array}{c}1.0083^{* * *} \\
(0.9394) \\
\end{array}$ & $\begin{array}{c}0.7251^{* * *} \\
(0.4370)\end{array}$ & $\begin{array}{c}0.7467^{* * *} \\
(0.4970) \\
\end{array}$ \\
\hline South Korea & $\begin{array}{c}i=1,705 \\
n=17,367\end{array}$ & $\begin{array}{c}0.9416^{* * *} \\
(0.9333) \\
\end{array}$ & $\begin{array}{c}0.7459^{* * *} \\
(0.5677) \\
\end{array}$ & $\begin{array}{c}0.9257^{* * *} \\
(0.8216) \\
\end{array}$ \\
\hline Taiwan & $\begin{array}{c}i=1,648 \\
n=16,402\end{array}$ & $\begin{array}{c}0.8117^{* * *} \\
(0.8183)\end{array}$ & $\begin{array}{c}0.5928^{* * *} \\
(0.4063)\end{array}$ & $\begin{array}{c}0.7861^{* * *} \\
(0.5630)\end{array}$ \\
\hline Turkey & $\begin{array}{c}i=213 \\
n=1,766\end{array}$ & $\begin{array}{c}0.8843^{* * *} \\
(0.7719)\end{array}$ & $\begin{array}{c}0.6856^{* * *} \\
(0.4949)\end{array}$ & $\begin{array}{c}0.8530^{* * *} \\
(0.6658)\end{array}$ \\
\hline United Arab Emirates & $\begin{array}{c}i=44 \\
n=413\end{array}$ & $\begin{array}{c}0.9555^{* * *} \\
(0.7843)\end{array}$ & $\begin{array}{c}0.1644^{* * *} \\
(0.0123)\end{array}$ & $\begin{array}{c}0.7958^{* * *} \\
(0.4489)\end{array}$ \\
\hline
\end{tabular}

Note: This table shows the coefficient of persistence $\left(\beta_{1}\right)$ and the adjusted $R^{2}$ (in parentheses) from the ordinary least squares (OLS) regressions for each country, according to the adapted equation 4. Errors are clustered at the firm level, and the estimation of standard errors is robust to heteroscedasticity and the firm-and industry-level error correlations. For every firm i in year $t$, $X$ is the sales per share (model 1), the earnings per share (model 2), or the dividend per share (model 3), IFRSexp is the number of years of mandatory International Financial Reporting Standards (IFRS) adoption, except for countries marked in bold, which did not adopt the IFRS in the analyzed period, and, therefore, this variable is excluded from the model, $\delta_{t}$ and $\gamma_{s}$ represent the year and industry fixed-effects, respectively, $i$ is the number of firms, $n$ is the number of year-observations. The highest sales ratio is observed for Qatar (1.0449), which suggests that if companies in Qatar earn United States dollars (USD) 1.00 of sales, then, on average, USD 1.05 will persist into next year's sales. Qatar is also the country with the highest average gross domestic product $(G D P)$ growth in this sample, which confirms this evidence and demonstrates that the growth of corporate sales is associated with a country's GDP growth. In contrast, the lowest sales persistence coefficient is observed for Taiwan (0.8117), wherefrom every USD 1.00 earned in sales in the current period, on average, 82 cents will persist into next year's sales. Compared to the Dechow and Schrand (2004) coefficient found for a sample of firms in the United States of America(0.84), in this study, only China and Taiwan show lower coefficients, with all the other countries showing more persistence of sales.

**, ${ }^{* * *}=$ significant at 5 and $1 \%$, respectively.

Source: Elaborated by the authors. 
The highest coefficient of earnings persistence is observed in Colombia (1.0041), and the lowest is observed in the United Arab Emirates (0.1644). This means that if a company earns USD 1.00 of earnings, then, on average, in Colombia, USD 1.00 will persist into next year's earnings, but in the United Arab Emirates, only 16 cents will persist in the next year. Compared to the Dechow and Schrand (2004) coefficient of earnings persistence (0.71) for the US market, in this study, in six of the 20 countries, the coefficient is lower (Brazil, China, Greece, Taiwan, Turkey, and the United Arab Emirates), and in the other 14 emerging countries, the earnings persistence is greater than the earnings persistence identified by Dechow and Schrand.

Table 5 also shows that dividend persistence is observed in all emerging countries, with the highest coefficient observed in Colombia (0.9852), and the lowest coefficient is observed in China (0.1008). Therefore, concerning dividends, if a firm pays USD 1.00 of dividends, then, on average, in Colombia, 99 cents will persist into next year's dividends, but in China, only 10 cents will persist in the next year. In general, by examining each emerging country, we note that dividend persistence is greater than earnings persistence $\left(\beta_{1}^{D P S}>\beta_{1}^{E P S}\right)$ in 14 of the 20 countries analyzed, where $\mathrm{H}_{1}$ is also confirmed individually.

In addition to past dividends $\left(D P S_{\mathrm{it}-1}\right)$, Lintner (1956) states that present earnings (EPS $S_{\text {it }}$ ) affect dividend persistence. For this author, it is expected that earnings have a positive influence on dividends in period $t$. For this reason, we estimate, in Table 6, the Lintner model for the sample of emerging countries (model 1), and we find that, in fact, the current earnings have relevance in explaining the current dividends (0.0392). Accordingly, if a company earns USD 1.00 of earnings, then, on average, 4 cents of these earnings will persist into next year's dividends. Nevertheless, in model 1, we find that even with the inclusion of current earnings, past dividends remain relevant (0.7603). For a sample of US firms in the period from 1918 to 1941, Lintner (1956) identified a larger coefficient for current earnings (0.15) and a smaller coefficient for past dividends (0.70). Thus, we can infer that, in recent years, past dividends are more important in emerging countries and current earnings are less important to explain current dividends when we compare these recent findings to emerging countries with the old Lintner findings for the United States of America (a developed country).

\section{Table 6}

Regressions for the Lintner model with earnings management, 2000-2016

\begin{tabular}{|c|c|c|c|c|}
\hline \multirow{2}{*}{ Variables } & \multirow{2}{*}{ Lintner model } & \multirow{2}{*}{$\begin{array}{c}\text { Modified } \\
\text { Lintner model }\end{array}$} & \multicolumn{2}{|c|}{ Control } \\
\hline & & & $|E M|_{i j t-1}$ & $S D(E M)_{\mathrm{ijt}-1}$ \\
\hline \multirow{2}{*}{$\left(\varnothing_{0}\right)$ Constant } & $0.0486^{* * *}$ & $0.0537^{* * *}$ & $0.0556^{* * *}$ & $0.0537^{* * *}$ \\
\hline & $(0.0074)$ & $(0.0077)$ & $(0.0062)$ & $(0.0061)$ \\
\hline \multirow{2}{*}{$\left(\varnothing_{1}\right) E P S_{i j t}$} & $0.0392 * * *$ & $0.0392 * * *$ & $0.0362^{* * *}$ & $0.0374^{* * *}$ \\
\hline & $(0.0019)$ & $(0.0019)$ & $(0.0006)$ & $(0.0005)$ \\
\hline \multirow{2}{*}{$\left(\varnothing_{2}\right) D P S_{i j t-1}$} & $0.7603^{* * *}$ & $0.7604^{* * *}$ & $0.7877^{* * *}$ & $0.7682^{* * *}$ \\
\hline & $(0.0107)$ & $(0.0107)$ & $(0.0036)$ & $(0.0030)$ \\
\hline \multirow[b]{2}{*}{$\left(\varnothing_{3}\right)$ IFRSexp $p_{j t-1}$} & $0.0016^{* *}$ & $0.0018^{* *}$ & $0.0011^{*}$ & $0.0011^{*}$ \\
\hline & $(0.0008)$ & $(0.0008)$ & $(0.0000)$ & $(0.0006)$ \\
\hline \multirow{2}{*}{$\left(\varnothing_{4}\right)$ Control } & & $0.0092 *$ & 0.0053 & $-0.0096^{* *}$ \\
\hline & & $(0.0048)$ & $(0.0057)$ & $(0.0050)$ \\
\hline \multirow{2}{*}{$\left(\varnothing_{5}\right)$ Control $\times E P S_{i j t}$} & & & $0.0158^{* * *}$ & $0.0087^{* * *}$ \\
\hline & & & $(0.0027)$ & $(0.0014)$ \\
\hline \multirow{2}{*}{$\left(\varnothing_{6}\right)$ Control $\times D P S_{i t-1}$} & & & $-0.1407^{* * *}$ & $-0.0348^{* * *}$ \\
\hline & & & $(0.0136)$ & $(0.0073)$ \\
\hline \multirow{2}{*}{$\left(\varnothing_{7}\right)$ Control $\times I F R S \exp _{j t-1}$} & & & 0.0024 & $0.0020^{*}$ \\
\hline & & & $(0.0020)$ & $(0.0012)$ \\
\hline$\left(\delta_{t}\right)$ Year dummies & Yes & Yes & Yes & Yes \\
\hline$\left(\gamma_{\mathrm{s}}\right)$ Industry dummies & Yes & Yes & Yes & Yes \\
\hline$\left(\theta_{\mathrm{j}}\right)$ Country dummies & Yes & Yes & Yes & Yes \\
\hline
\end{tabular}


Table 6

Cont.

\begin{tabular}{lcccc}
\hline Variables & Lintner model & $\begin{array}{c}\text { Modified } \\
\text { Lintner model }\end{array}$ & \multicolumn{2}{c}{ Control } \\
\cline { 4 - 5 } F statistic & $727.96^{* * *}$ & $712.34^{* * *}$ & $611.31^{* * *}$ & $\boldsymbol{S D ( E M )}$ \\
\hline Adjusted R ${ }^{2}$ & 0.8219 & 0.8219 & 0.8235 & $628.23^{* * *}$ \\
\hline Firms & 7,134 & 7,134 & 7,134 & 0.8229 \\
\hline Observations & 57,059 & 57,059 & 57,059 & 57,059 \\
\hline
\end{tabular}

Note: This table shows the coefficient estimates and standard errors (in parentheses) from the ordinary least squares (OLS) regressions. Errors are clustered at the firm level and the estimation of standard errors is robust to heteroscedasticity and the firm-, industry-, and country-level error correlations. For every firm i in country $j$ and year $t$, DPS ijt is the dividend per share in year $t, E P S_{i j t}$ is the earnings per share in year $t, D P S_{i j t-1}$ is the dividend per share in year $t-1$, Control $l_{i j t-1}$ is the control for earnings management, assuming the discretionary accruals (EM) in model 2, the discretionary accruals module (|EM|) in model 3, and the $S D$ of discretionary accruals $(S D(E M))$ in model 4, IFRSexp jt- $1_{1}$ is the number of years of mandatory International Financial Reporting Standards (IFRS) adoption, and $\delta_{t}, \gamma_{s}$, and $\theta_{j}$ represent the year, industry, and country fixed-effects, respectively. $*, * *,{ }^{* *}=$ significant at 10,5 , and $1 \%$, respectively.

Source: Elaborated by the authors.

In this study, we assume that, in addition to the current earnings considered in the Lintner model, the volume of earnings management can affect dividend persistence (Daniel et al., 2008; Martinez, 2008). Therefore, we add this point to this discussion. In Table 6, models 2 to 4 consider the effects of earnings management on dividend persistence. In model 2 , we verify that the effect of past earnings management on current dividends is positive (0.0092). When we analyze the effects of earnings management volume ( $|E M|$ in model 3$)$ on the Lintner model, we can observe that the relevance of current earnings in explaining current dividends is increased (0.0158), while the relevance of past dividends is decreased (-0.1407). Additionally, when the SD of earnings management $[S D(E M)$ in model 4$]$ is considered in the Lintner model, we note that the relevance of current earnings in explaining current dividends is increased (0.0087), while the relevance of past dividends is decreased $(-0.0348)$.

These findings reveal that, based on the model of Lintner (1956) in emerging countries, earnings management has a positive effect on earnings $\left(\varnothing_{5}>0\right)$, but a negative effect on dividend persistence $\left(\varnothing_{6}<0\right)$. We note that dividend persistence continues even in a scenario with earnings management, which is consistent with the US evidence of Lintner (1956) and the Jordanian evidence of Al-Najjar (2009). However, this earnings management tends to decrease dividend persistence over time, especially because of the reversal tendency of this management, according to Rodrigues Sobrinho et al. (2014) and Srikanth and Durga Prasad (2015). Therefore, there is evidence for $\mathrm{H}_{2}$ in the emerging markets. These findings remain even when South Korea, India, and Taiwan are removed from the sample (see Table B in the Appendix).

Based on the assumption that a country's macroeconomic volatility may affect the dividend persistence of firms, in Table 7, we re-estimate Lintner's original model (for a subsample adjusted by the lagged variables) and two modified versions to control a country's economic performance and sovereign risk. Again, model 1 of Table 7 reveals that dividend persistence $\left(\varnothing_{2}>0\right)$ remains at the conventional levels of significance, with coefficients similar to the coefficients identified in model 1 of Table 6 . In model 2, we can observe that an increase of $1 \%$ in past GDP is positively associated with an increase of 0.07 cents in next year's dividends $\left(\varnothing_{4}^{G D P}=0.0007\right)$.

When we moderate dividend persistence by GDP growth, we find that, in addition to dividend persistence $\left(\varnothing_{2}^{G D P}=0.7157\right)$, it is increased when a country's GDP grows $\left(\varnothing_{6}^{G D P}=0.0106\right)$. In general, when a country's GDP grows $1 \%$, on average, 1 cent more will persist into next year's dividends for firms. This finding reveals that the improvement of a country's economic performance positively influences an increase in a firm's performance (Malik \& Temple, 2009), which improves the predictability of its earnings and dividends. This is according to $\mathrm{H}_{4}$, which is confirmed for the emerging countries of the sample. 
Table 7

Regressions for the Lintner model, GDP, and SRI, 2000-2016

\begin{tabular}{|c|c|c|c|}
\hline \multirow{2}{*}{ Variables } & \multirow{2}{*}{ Lintner model } & \multicolumn{2}{|c|}{ Control } \\
\hline & & $G D P_{\mathrm{jt}-1}$ & $S \boldsymbol{R} \boldsymbol{I}_{\mathrm{j} t-1}$ \\
\hline \multirow{2}{*}{$\left(\varnothing_{0}\right)$ Constant } & $0.0388^{* * *}$ & $0.0409 * * *$ & $0.0438^{* * *}$ \\
\hline & $(0.0076)$ & $(0.0078)$ & $(0.0108)$ \\
\hline \multirow{2}{*}{$\left(\varnothing_{1}\right) E P S_{i t}$} & $0.0397^{* * *}$ & $0.0447^{* * *}$ & $0.0628^{* * *}$ \\
\hline & $(0.0019)$ & $(0.0035)$ & $(0.0090)$ \\
\hline \multirow{2}{*}{$\left(\varnothing_{2}\right) D P S_{i t-1}$} & $0.7559^{* * *}$ & $0.7157^{* * *}$ & $0.6171^{* * *}$ \\
\hline & $(0.0109)$ & $(0.0206)$ & $(0.0453)$ \\
\hline \multirow{2}{*}{$\left(\varnothing_{3}\right) I F R S \exp p_{j t-1}$} & $0.0017^{* *}$ & 0.0013 & 0.0012 \\
\hline & $(0.0007)$ & $(0.0010)$ & $(0.0020)$ \\
\hline \multirow{2}{*}{$\left(\varnothing_{4}\right)$ Control } & & $0.0007^{* * *}$ & 0.0007 \\
\hline & & $(0.0004)$ & $(0.0008)$ \\
\hline \multirow{2}{*}{$\left(\varnothing_{5}\right)$ Control $\times E P S_{i t}$} & & $-0.0013^{*}$ & $-0.0020^{* * *}$ \\
\hline & & $(0.0007)$ & $(0.0007)$ \\
\hline \multirow{2}{*}{$\left(\varnothing_{6}\right)$ Control $\times D P S_{i t-1}$} & & $0.0106^{* *}$ & $0.0128^{* * *}$ \\
\hline & & $(0.0043)$ & (0.0039) \\
\hline \multirow{2}{*}{$\left(\varnothing_{7}\right)$ Control $\times I F R S \exp _{j t-1}$} & & -0.0001 & -0.0001 \\
\hline & & $(0.0001)$ & $(0.0001)$ \\
\hline$\left(\delta_{\mathrm{t}}\right)$ Year dummies & Yes & Yes & Yes \\
\hline$\left(\gamma_{\mathrm{s}}\right)$ Industry dummies & Yes & Yes & Yes \\
\hline$\left(\theta_{\mathrm{j}}\right)$ Country dummies & Yes & Yes & Yes \\
\hline F statistic & $691.23^{* * *}$ & $626.73^{* * *}$ & $686.35^{* * *}$ \\
\hline Adjusted $\mathrm{R}^{2}$ & 0.8190 & 0.8195 & 0.8197 \\
\hline Firms & 7,137 & 7,137 & 7,137 \\
\hline Observations & 58,426 & 58,426 & 58,426 \\
\hline
\end{tabular}

Note: This table shows the coefficient estimates and standard errors (in parentheses) from the ordinary least squares (OLS) regressions. Errors are clustered at the firm level and the estimation of standard errors is robust to heteroscedasticity and the firm-, industry-, and country-level error correlations. For every firm $i$ in country $j$ and year $t, D P S_{i j t}$ is the dividend per share in year $t, E P S_{i j t}$ is the earnings per share in year $t, D P S_{i j t-1}$ is the dividend per share in year $t-1$, IFRSexp jt -1 is the number of years of mandatory International Financial Reporting Standards (IFRS) adoption, GDP $P_{j t-1}$ is the percentage of the gross domestic product $(G D P)$ growth of each country between years $t-2$ and $t-1, S R I_{j t}$ is the sovereign risk indicator for each country in year $t-1, \delta_{t}$, $\gamma_{s}$, and $\theta_{j}$ represent the year, industry, and country fixed-effects, respectively.

$*, * *, * *=$ significant at 10,5 , and $1 \%$, respectively.

Source: Elaborated by the authors.

Finally, model 3 of Table 7 reveals that even in the face of a country's sovereign risk control, dividend persistence continues $\left(\varnothing_{2}^{\text {SRI }}=0.6171\right)$. Individually, changing a country's rating to a higher or lower degree on the sovereign risk scale shows no significant effect on next year's dividends $\left(\varnothing_{4}^{S R I}=0\right)$. However, when the SRI score is used to moderate the dividend persistence of firms, we find a positive effect of the change in rating to a higher degree scale (lower risk) on dividend persistence $\left(\varnothing_{6}^{S R I}=0.0128\right)$, which affirms the assumption that the reduction of an emerging country's economic instability supports the predictability of firms' performance (Malik \& Temple, 2009; Oshiro \& Saruwatari, 2005).

In this study, in general, the advancement of one degree on the Standard and Poor's rating scale by an emerging country represents, on average, 1 cent more in next year's dividends for firms. Thus, the fourth and final hypothesis of this study is confirmed. And, again, we note that the findings are not conducted by South Korea, India, and Taiwan (see Table $\mathrm{C}$ in the Appendix). 


\section{CONCLUSION}

The results of our study indicate that in the major emerging markets, companies that distribute the most dividends have lower earnings management, are more profitable, have lower financial leverage, and have a higher sales volume. These characteristics of emerging countries also affect the volume of profits distributed by firms, since GDP growth tends to be associated with the growth of a company, which makes the company retain more of its earnings to support its growth. We find that earnings are persistent in emerging markets, like in developed countries, but additionally, we find that dividends tend to be more persistent over time.

This finding is a relevant one for emerging markets that converges with the supporting literature and demonstrates that, in fact, dividends may be a better input in the valuation models in emerging markets because they are less subject to the effects of earnings management. This property of dividends is especially true because these countries have a riskier business environment, and keeping dividend payments less volatile is helpful for firms to improve their reputation and reduce investor risk.

Lintner demonstrates that, in a developed country, the current dividends paid by firms are explained not only by past dividends, but also by current profits. This is a true condition in emerging countries because, usually, the volume of paid dividends is a function of a firm's reported earnings due to the DP ratio set by the managers of the company. From this, we contribute to this literature by demonstrating that firms in emerging countries tend to manage their earnings to meet market expectations, especially concerning the firm's performance, which has a negative effect on dividend persistence. Thus, on average, although dividends have their persistence reduced by this earnings management, it remains less volatile than corporate earnings, which, again, qualifies dividend persistence as the best input for the valuation models in emerging countries.

Another relevant contribution of this study is the confirmation that, in emerging markets, the reduction of macroeconomic volatility and uncertainties about a country's performance and risk improves the predictability of corporate performance and increases the persistence of dividends over time. This is further evidence that supports the use of dividend information as an input to valuation models, especially when there is less uncertainty in the emerging country and a lower volume of earnings management in the firm.

Finally, our findings generated the following questions that were not addressed by methodological or DataStream peculiarities and that we suggest as future developments for this research: (i) How do the legal specificities of each country affect dividend persistence by comparing the events between countries? (ii) How do the specific financial crises of each country influence dividend persistence in the presence of earnings management? (iii) How does the way of earnings management (more or less) affect the dividend persistence of firms? (iv) What are the motivations that lead firms to seek greater dividend persistence, even in periods in which they have reported losses?

\section{REFERENCES}

Al-Kuwari, D. (2009). Determinants of the dividend policy in emerging stock exchanges: The case of GCC countries. Global Economy \& Finance Journal, 2(2), 38 -63.

Al-Najjar, B. (2009). Dividend behaviour and smoothing new evidence from Jordanian panel data. Studies in Economics and Finance, 2(2), 38-63.

Chan, K. F., Powell, J. G., Shi, J., \& Smith, T. (2018). Dividend persistence and dividend behaviour. Accounting and Finance, 58(1), 127-147.

Choi, J.-H., Kim, J.-B., \& Lee, J. J. (2011). Value relevance of discretionary accruals in the Asian financial crisis of 19971998. Journal of Accounting and Public Policy, 30(2), 166-187.
Damodaran, A. (2012). Investment valuation: Tools and techniques for determining the value of any asset (3rd ed.). Wiley \& Sons.

Daniel, N. D., Denis, D. J., \& Naveen, L. (2008). Do firms manage earnings to meet dividend thresholds? Journal of Accounting \& Economics, 45(1), 2-26.

Dechow, P., Ge, W., \& Schrand, C. (2010). Understanding earnings quality: A review of the proxies, their determinants, and their consequences. Journal of Accounting and Economics, 50(2-3), 344-401.

Dechow, P., Hutton, A. P., Kim, J. H., \& Sloan, R. G. (2012). Detecting earnings management: A new approach. Journal of Accounting Research, 50(2), 275-334. 
Dechow, P., \& Schrand, C. (2004). Earnings quality. CFA Digest, 34(4), 82-85.

Dichev, I. D., \& Tang, V. W. (2009). Earnings volatility and earnings predictability. Journal of Accounting and Economics, 47(1-2), 160-181.

Dimitras, A. I., Kyriakou, M. I., \& Iatridis, G. (2015). Financial crisis, GDP variation, and earnings management in Europe. Research in International Business and Finance, 34(C), 338354.

Dong, M., \& Stettler, A. (2011). Estimating firm-level and country-level effects in cross-sectional analyses: An application of hierarchical modeling in corporate disclosure studies. The International Journal of Accounting, 46(3), 271303.

Doukakis, L. C. (2014). The effect of mandatory IFRS adoption on real and accrual-based earnings management activities. Journal of Accounting and Public Policy, 33(6), 551-572.

Enomoto, M., Kimura, F., \& Yamaguchi, T. (2015). Accrual-based and real earnings management: An international comparison for investor protection. Journal of Contemporary Accounting \& Economics, 11(3), 183-198.

Ghysels, E., Plazzi, A., \& Valkanov, R. (2016). Why invest in emerging markets? The role of conditional return asymmetry. The Journal of Finance, 71(5), 2145-2192.

Gordon, M. J. (1963). Optimal Investment and financing policy. The Journal of Finance, 18(2), 264-272.

Houqe, M. N., \& Monem, R. M. (2016). IFRS adoption, extent of disclosure, and perceived corruption: A cross-country study. The International Journal of Accounting, 51(3), 363-378.

Ismail, W. A. W., Kamarudin, K. A., Tony, V. Z., \& Dunstan, K. (2013). Earnings quality and the adoption of IFRS-based accounting standards. Asian Review of Accounting, 21(1), 53-73.

Jabbouri, I. (2016). Determinants of corporate dividend policy in emerging markets: Evidence from MENA stock markets. Research in International Business and Finance, 37, 283298.

Johnson, M. (1999). Business cycles and the relation between security returns and earnings. Review of Accounting Studies, 4(2), 93-117.
La Porta, R., Lopez-De-Silanes, F., Shleifer, A., \& Vishny, R. W. (1997). Legal determinants of external finance. The Journal of Finance, 52(3), 1131.

La Porta, R., Lopez-De-Silanes, F., Shleifer, A., \& Vishny, R. W. (2000). Agency problems and dividend policies around the world. Journal of Finance, 55(1), 1-33.

Lintner, J. (1956). Distribution of incomes of corporations among dividends, retained earnings, and taxes. American Economic Review, 46(2), 97-113.

Malik, A., \& Temple, J. R. W. (2009). The geography of output volatility. Journal of Development Economics, 90(2), 163-178.

Marsh, T. A., \& Merton, R. C. (1987). Dividend behavior for the aggregate stock market. Journal of Business, 60(1), 1-40.

Martinez, A. L. (2008). Detecting earnings management in Brazil: estimating discretionary accruals. Revista Contabilidade o Finanças, 19(46), 7-17.

Miller, M. H., \& Modigliani, F. (1961). Dividend policy, growth, and the valuation of shares. Journal of Business, 34(4), 411-433.

Oshiro, N., \& Saruwatari, Y. (2005). Quantification of sovereign risk: Using the information in equity market prices. Emerging Markets Review, 6(4), 346-362.

Pelucio-Grecco, M. C., Geron, C. M. S., Grecco, G. B., \& Lima, J. P. C. (2014). The effect of IFRS on earnings management in Brazilian non-financial public companies. Emerging Markets Review, 21(C), 42-66.

Petersen, M. A. (2009). Estimating standard errors in finance panel data sets: Comparing approaches. Review of Financial Studies, 22(1), 435-480.

Rodrigues Sobrinho, W. B., Rodrigues, H. S., \& Sarlo, A., Neto. (2014). Dividendos e accruals discricionários: um estudo sobre a relação entre a política de distribuição de dividendos e a qualidade dos lucros. Revista Contemporânea de Contabilidade, 11(24), 3-24.

Silva, A. F. da, Weffort, E. F. J., Flores, E. da S., \& Silva, G. P. da. (2014). Earnings management and economic crises in the Brazilian capital market. Revista de Administração de Empresas, 54(3), 268-283.

Srikanth, P., \& Durga Prasad, M. N. (2015). Impact of earnings management on dividend policy: Empirical evidence from India. Nitte Management Review, 25(1), 183-205. 


\section{APPENDIX}

\section{Table A}

Without India, South Korea, and Taiwan - Regressions for sales, earnings, and dividend persistence, 2000-2016

\begin{tabular}{|c|c|c|c|}
\hline Variable & $\begin{array}{c}\text { Model } 1 \\
\text { (SPS) }\end{array}$ & $\begin{array}{c}\text { Model } 2 \\
\text { (EPS) }\end{array}$ & $\begin{array}{l}\text { Model } 3 \\
\text { (DPS) }\end{array}$ \\
\hline$\left(\beta_{0}\right)$ Constant & $\begin{array}{l}-0.4499 \\
(0.3853)\end{array}$ & $\begin{array}{l}-0.0393 \\
(0.0833)\end{array}$ & $\begin{array}{c}0.0545^{* * *} \\
(0.0162)\end{array}$ \\
\hline$\left(\beta_{1}\right) X_{i t-1}$ & $\begin{array}{c}0.9471^{* * *} \\
(0.0119)\end{array}$ & $\begin{array}{c}0.7527^{* * *} \\
(0.0268)\end{array}$ & $\begin{array}{c}0.8337^{* * *} \\
(0.0134)\end{array}$ \\
\hline$\left(\beta_{2}\right)$ IFRSexp $\operatorname{ext}_{\mathrm{j}-1}$ & $\begin{array}{c}0.0175 \\
(0.0392)\end{array}$ & $\begin{array}{l}-0.0030 \\
(0.0044)\end{array}$ & $\begin{array}{c}0.0006 \\
(0.0009)\end{array}$ \\
\hline$\left(\delta_{\mathrm{t}}\right)$ Year dummies & Yes & Yes & Yes \\
\hline$\left(\gamma_{\mathrm{s}}\right)$ Industry dummies & Yes & Yes & Yes \\
\hline$\left(\theta_{\mathrm{j}}\right)$ Country dummies & Yes & Yes & Yes \\
\hline F statistic & $684.04^{* * *}$ & $100.91^{* * *}$ & $358.44^{* * *}$ \\
\hline Adjusted R² & 0.9229 & 0.5987 & 0.7207 \\
\hline Firms & 2.104 & 2.104 & 2.104 \\
\hline Observations & 17.272 & 17.272 & 17.272 \\
\hline
\end{tabular}

Note: This table shows the coefficient estimates and standard errors (in parentheses) from the OLS regressions. Errors are clustered at the firm level, and the estimation of standard errors is robust to heteroscedasticity and the firm-, industry-, and country-level error correlations. For every firm $i$ in country $j$ and year $t, X$ is the Sales per Share (Model 1), the Earnings per Share (Model 2) or the Dividend per Share (Model 3); IFRSexp is the number of years of mandatory IFRS adoption; $\delta_{t}, \gamma_{s}$ and $\theta_{j}$ represent the year, industry, and country fixed-effects, respectively; and ${ }^{* * *}$ is significant at $1 \%$.

Source: Elaborated by the authors.

\section{Table B}

Without India, South Korea, and Taiwan - Regressions for the Lintner model with earnings management, 2000-2016

\begin{tabular}{|c|c|c|c|c|}
\hline \multirow{2}{*}{ Variables } & \multirow{2}{*}{ Lintner model } & \multirow{2}{*}{$\begin{array}{c}\text { Modified } \\
\text { Lintner model }\end{array}$} & \multicolumn{2}{|c|}{ Control } \\
\hline & & & $|E M|_{i j t-1}$ & $S D(E M)_{\mathrm{ijt}-1}$ \\
\hline \multirow{2}{*}{$\left(\varnothing_{0}\right)$ Constant } & $0.0637^{* * *}$ & $0.0531^{* * *}$ & $0.0504^{* * *}$ & $0.0494^{* * *}$ \\
\hline & $(0.0162)$ & $(0.0111)$ & $(0.0118)$ & $(0.0121)$ \\
\hline \multirow{2}{*}{$\left(\varnothing_{1}\right) E P S_{i j t}$} & $0.0507^{* * *}$ & $0.0509^{* * *}$ & $0.0514^{* * *}$ & $0.0565^{* * *}$ \\
\hline & $(0.0037)$ & $(0.0037)$ & $(0.0014)$ & $(0.0020)$ \\
\hline \multirow{2}{*}{$\left(\varnothing_{2}\right) D P S_{i j t-1}$} & $0.7160^{* * *}$ & $0.7184^{* * *}$ & $0.7350^{* * *}$ & $0.7379 * * *$ \\
\hline & $(0.0153)$ & (0.0149) & $(0.0062)$ & $(0.0093)$ \\
\hline \multirow{2}{*}{$\left(\varnothing_{3}\right)$ IFRSexp $p_{j t-1}$} & -0.0001 & -0.0002 & 0.0005 & 0.0011 \\
\hline & $(0.0008)$ & $(0.0008)$ & $(0.0009)$ & $(0.0011)$ \\
\hline \multirow{2}{*}{$\left(\varnothing_{4}\right)$ Control } & & 0.0184 & 0.0265 & 0.0238 \\
\hline & & $(0.0180)$ & $(0.0312)$ & $(0.0382)$ \\
\hline \multirow{2}{*}{$\left(\varnothing_{5}\right)$ Control $\times E P S_{i j t}$} & & & -0.0077 & $-0.0675^{* * *}$ \\
\hline & & & $(0.0156)$ & $(0.0204)$ \\
\hline \multirow{2}{*}{$\left(\varnothing_{6}\right)$ Control $\times D P S_{i t-1}$} & & & $-0.3222^{* * *}$ & $-0.2414^{* * *}$ \\
\hline & & & $(0.0694)$ & $(0.0939)$ \\
\hline \multirow{2}{*}{$\left(\varnothing_{7}\right)$ Control $\times I F R S \exp _{j t-1}$} & & & -0.0080 & -0.0128 \\
\hline & & & $(0.0065)$ & $(0.0079)$ \\
\hline$\left(\delta_{t}\right)$ Year dummies & Yes & Yes & Yes & Yes \\
\hline$\left(\gamma_{\mathrm{s}}\right)$ Industry dummies & Yes & Yes & Yes & Yes \\
\hline$\left(\theta_{\mathrm{j}}\right)$ Country dummies & Yes & Yes & Yes & Yes \\
\hline F statistic & $376.37^{* * *}$ & $384.47^{* * *}$ & $1,170.73^{* * *}$ & $1,171.28^{* * *}$ \\
\hline
\end{tabular}


Table B

Cont.

\begin{tabular}{|c|c|c|c|c|}
\hline \multirow{2}{*}{ Variables } & \multirow{2}{*}{ Lintner model } & \multirow{2}{*}{$\begin{array}{c}\text { Modified } \\
\text { Lintner model }\end{array}$} & \multicolumn{2}{|c|}{ Control } \\
\hline & & & $|E M|_{i \mathrm{jt}-1}$ & $S D(E M)_{\mathrm{ijt}-1}$ \\
\hline Adjusted $\mathrm{R}^{2}$ & 0.7507 & 0.7562 & 0.7561 & 0.7562 \\
\hline Firms & 2,102 & 2,102 & 2,102 & 2,102 \\
\hline Observations & 16,605 & 16,605 & 16,605 & 16,605 \\
\hline
\end{tabular}

Note: This table shows the coefficient estimates and standard errors (in parentheses) from the OLS regressions. Errors are clustered at the firm level, and the estimation of standard errors is robust to heteroscedasticity and the firm-, industry-, and country-level error correlations. For every firm i in country $j$ and year $t$, DPS $i_{i j t}$ is the Dividend per Share in year $t$; EPS $S_{i j t}$ is the Earnings per Share in year $t$; DPS $S_{i j t-1}$ is the Dividend per Share in year $t-1$; Control $l_{i j t-1}$ is the control for earnings management, assuming the discretionary accruals (EM) in Model 2, the discretionary accruals module (|EM|) in Model 3, and the standard deviation of discretionary accruals $(S D(E M))$ in Model 4 ; IFRSexp $p_{j t-1}$ is the number of years of mandatory IFRS adoption; $\delta_{t}, \gamma_{s}$ and $\theta_{j}$ represent the year, industry, and country fixed-effects, respectively; and ${ }^{* * *}$ is significant at $1 \%$.

Source: Elaborated by the authors.

Table C

Without India, South Korea, and Taiwan - Regressions for the Lintner model, GDP, and SRI, 2000-2016

\begin{tabular}{|c|c|c|c|}
\hline \multirow{2}{*}{ Variables } & \multirow{2}{*}{ Lintner model } & \multicolumn{2}{|c|}{ Control } \\
\hline & & $G D P_{\mathrm{jt}-1}$ & $\boldsymbol{S} \boldsymbol{R} \boldsymbol{I}_{\mathrm{j} t-1}$ \\
\hline \multirow{2}{*}{$\left(\varnothing_{0}\right)$ Constant } & $0.0637^{* * *}$ & $0.0615^{* * *}$ & $0.0614^{* * *}$ \\
\hline & $(0.0162)$ & $(0.0167)$ & $(0.0169)$ \\
\hline \multirow{2}{*}{$\left(\varnothing_{1}\right) E P S_{i t}$} & $0.0507^{* * *}$ & $0.0494^{* * *}$ & $0.0608^{* * *}$ \\
\hline & $(0.0037)$ & $(0.0049)$ & $(0.0140)$ \\
\hline \multirow{2}{*}{$\left(\varnothing_{2}\right) D P S_{i t-1}$} & $0.7160^{* * *}$ & $0.6860^{* * *}$ & $0.6377^{* * *}$ \\
\hline & $(0.0153)$ & $(0.0216)$ & $(0.0450)$ \\
\hline \multirow{2}{*}{$\left(\varnothing_{3}\right) I F R S \exp _{j t-1}$} & -0.0001 & 0.0001 & 0.0001 \\
\hline & $(0.0008)$ & $(0.0013)$ & $(0.0019)$ \\
\hline \multirow{2}{*}{$\left(\varnothing_{4}\right)$ Control } & & 0.0003 & 0.0010 \\
\hline & & $(0.0008)$ & $(0.0011)$ \\
\hline \multirow{2}{*}{$\left(\varnothing_{5}\right)$ Control $\times E P S_{i t}$} & & 0.0003 & -0.0011 \\
\hline & & $(0.0012)$ & $(0.0014)$ \\
\hline \multirow{2}{*}{$\left(\varnothing_{6}\right)$ Control $\times D P S_{i t-1}$} & & $0.0093^{* *}$ & $0.0083^{*}$ \\
\hline & & $(0.0046)$ & $(0.0047)$ \\
\hline \multirow{2}{*}{$\left(\varnothing_{7}\right)$ Control $\times I F R S \exp _{j t-1}$} & & -0.0001 & -0.0001 \\
\hline & & $(0.0002)$ & $(0.0002)$ \\
\hline$\left(\delta_{\mathrm{t}}\right)$ Year dummies & Yes & Yes & Yes \\
\hline$\left(\gamma_{\mathrm{s}}\right)$ Industry dummies & Yes & Yes & Yes \\
\hline$\left(\theta_{\mathrm{j}}\right)$ Country dummies & Yes & Yes & Yes \\
\hline F statistic & $376.37^{* * *}$ & $346.10^{* * *}$ & $352.54^{* * *}$ \\
\hline Adjusted R2 & 0.7507 & 0.7520 & 0.7512 \\
\hline Firms & 2,104 & 2,104 & 2,104 \\
\hline Observations & 17,272 & 17,272 & 17,272 \\
\hline
\end{tabular}

Note: This table shows the coefficient estimates and standard errors (in parentheses) from the OLS regressions. Errors are clustered at the firm level, and the estimation of standard errors is robust to heteroscedasticity and the firm-, industry-, and country-level error correlations. For every firm $i$ in country $j$ and year $t$, DPS $S_{i j t}$ is the Dividend per Share in year $t$; EPS $i j t$ is the Earnings per Share in year $t$; DPS ${ }_{i j t-1}$ is the Dividend per Share in year $t-1$; IFRSexp jt-1 $_{1}$ is the number of years of mandatory IFRS adoption; GDP $P_{j-1}$ is the percentage of the Gross Domestic Product growth of eachountry between years $t-2$ and $t-1 ; S R l_{j t-1}$ is the Sovereign Risk Indicator for each country in year $t-1 ; \delta_{t}, \gamma_{s}$ and $\theta_{j}$ represent the year, industry, and country fixed-effects, respectively; and * is significant at 10\%,** is significant at $5 \%$, and *** is significant at $1 \%$.

Source: Elaborated by the authors. 